IZA DP No. 5348

Female Labour Supply and Spousal Education

Kerry L. Papps

November 2010 


\title{
Female Labour Supply and Spousal Education
}

\author{
Kerry L. Papps \\ Nuffield College, University of Oxford \\ and IZA
}

\section{Discussion Paper No. 5348 \\ November 2010}

\author{
IZA \\ P.O. Box 7240 \\ 53072 Bonn \\ Germany \\ Phone: +49-228-3894-0 \\ Fax: +49-228-3894-180 \\ E-mail: iza@iza.org
}

\begin{abstract}
Any opinions expressed here are those of the author(s) and not those of IZA. Research published in this series may include views on policy, but the institute itself takes no institutional policy positions.

The Institute for the Study of Labor (IZA) in Bonn is a local and virtual international research center and a place of communication between science, politics and business. IZA is an independent nonprofit organization supported by Deutsche Post Foundation. The center is associated with the University of Bonn and offers a stimulating research environment through its international network, workshops and conferences, data service, project support, research visits and doctoral program. IZA engages in (i) original and internationally competitive research in all fields of labor economics, (ii) development of policy concepts, and (iii) dissemination of research results and concepts to the interested public.
\end{abstract}

IZA Discussion Papers often represent preliminary work and are circulated to encourage discussion. Citation of such a paper should account for its provisional character. A revised version may be available directly from the author. 
IZA Discussion Paper No. 5348

November 2010

\section{ABSTRACT \\ Female Labour Supply and Spousal Education}

Three hypotheses are given to explain why a married woman's work hours might be related to her husband's education, even controlling for his wage rate. Data for a single cohort of women from the NLSY 1979 suggest that women's work hours are positively related to spousal education at the time of marriage but also fall more rapidly over time after marriage among those with the most educated husbands. Cross-sectional data from the CPS for 19802010 indicate that the latter effect appears to have increased since 2000. Both men's and women's preferences for a traditional division of labour within the household are found to be negatively related to the husband's education among newlyweds but to rise faster over the course of a marriage when the husband is highly educated. Overall, the results provide evidence consistent with both marital sorting on the basis of attitudes to female work and changes in tastes that are influenced by marital quality. Little support is found for the argument that spousal education measures non-market productivity.

\section{NON-TECHNICAL SUMMARY}

Men's education is found to influence their wives' work hours, even when holding the wages of both spouses constant. Wives of well-educated men work long hours at the time of marriage; however, they also withdraw from the labour market more rapidly than other women after marriage. As a result, there is a hump-shaped relationship between women's hours and husbands' education across the full population of married couples.

JEL Classification: J16, J22, J24

Keywords: labour supply, households, education

Corresponding author:

Kerry L. Papps

Department of Economics

University of Oxford

Manor Road Building

Oxford, OX1 3UQ

United Kingdom

E-mail: kerry.papps@economics.ox.ac.uk 


\section{Introduction}

A woman, in any rank of life, ought to know whatever her husband is likely to know, but to know it in a different way. His command of it should be foundational and progressive; hers, general and accomplished for daily and helpful use. Not but that it would often be wiser in men to learn things in a womanly sort of way, for present use, and to seek for the discipline and training of their mental powers in such branches of study as will be afterwards fittest for social service; but, speaking broadly, a man ought to know any language or science he learns, thoroughly - while a woman ought to know the same language, or science, only so far as may enable her to sympathize in her husband's pleasures, and in those of his best friends.

John Ruskin, “Of Queens’ Gardens” (1865)

After expanding rapidly during the 1980s, labour force participation among married women stagnated during the 1990s and even fell slightly during the last decade. This pattern does not appear to have been caused by economic factors, since women's wages grew rapidly throughout this period and the opportunity costs of labour market time, in the form of the cost of child care and housekeeping, are likely to have fallen. Instead, some authors have pointed to the possibility that changes in preferences for household production, including raising children, have been at least partly responsible for the slowdown in labour supply among married women. In particular, an influential 2003 New York Times article by Lisa Belkin described a trend among highly-educated women of withdrawing from the labour market after marriage. However, subsequent empirical research has found little support for this socalled "opt-out revolution”. Rather, women have become steadily less likely to exit the labour market upon childbirth over recent decades, regardless of their education level (Goldin 2006; Fortin 2008; Percheski 2008; Antecol 2010), although there is some evidence that fertility has increased lately among educated women (Vere 2007; Shang and Weinberg 2009).

One potential explanation is that the observed changes in women's labour market behaviour have been the result of changes in their husbands' characteristics. At first glance, this seems an unlikely proposition, since husbands' wage rates have had an increasingly weak effect on married women's labour supply (Blau and Kahn 2007) and household production (Connelly and Kimmel 2007) in recent decades. There is little evidence, however, that other spousal characteristics have become similarly unimportant. As well as measuring his human capital, a husband's education level is likely to reflect many non-economic attributes, such as his ability to perform household tasks, his taste for work and his taste for a traditional arrangement of roles within the household. Women may be more likely to work if they have husbands who 
place little value on household production or who are very productive at home. Conversely, they may be less likely to work if their husbands are particularly attached to their jobs or have high future earnings. In either case, women's labour supply will be related to the education of their husbands, even after controlling for the current wage rate of the latter.

Moreover, although little noted, most of the women referred to in Belkin's article and subsequent media reports were married to equally highly-educated men. In light of this fact, rather than being a function of women's education, the opt-out revolution might instead manifest itself as a bigger decline in labour supply after marriage among women with highly-educated husbands compared to other women with the same education level. The fact that researchers have found no variation in labour supply behaviour after marriage between women from different education groups may overlook the importance of differences in their husbands' education.

This aim of this paper is to examine whether a man's education has an effect on his wife's labour market behaviour, after controlling for his wages. Using a simple model of household production, three possible explanations for a relationship between labour supply and spousal education are given. Each yields different predictions regarding the direction of the relationship, how it should vary over the course of a marriage and whether a pattern should also be seen in women's preferences for market versus non-market work. These predictions are then tested using 30 years of data on a single cohort of American women from the National Longitudinal Survey of Youth (NLSY) 1979, as well as four cross-sections of data from the Current Population Survey (CPS) spanning the same time period (specifically, 1980-2010).

The results indicate that spousal education has a strong positive effect on a woman's work hours at the time of marriage, which is consistent with sorting in the marriage market on the basis of attitudes to female work. However, over time hours are found to fall fastest among those with the most well-educated husbands, so that across the full population of married women an inverse U-shaped relationship between hours and spousal education is observed. This is consistent with a scenario in which preferences over the division of labour within the household change the longer people are married and are affected by marital quality. Little evidence is found to support the hypothesis that spousal education measures a spouse's non-market productivity. 


\section{Previous work and hypotheses}

Although studies of female labour supply routinely include husbands' education as a explanatory variable, very few have focused on the magnitude and direction of its effect, once wages are controlled for. Pencavel (1998) used 1990 Census data and uncovered a negative relationship between a husband's education and his wife's work hours, which was stronger for those couples with children aged under 6 years. In contrast, using a sample of Chinese twins to control for omitted variable bias, Huang et al. (2009) found that a man's education affects his wife's wages but not her work hours.

Pencavel speculated that once wages have been held constant, more education indicates greater non-market productivity, in the form of better health or better childraising ability. Pencavel presumably believed that women substitute time on both market and household work with leisure time when their husbands are more educated (given the negative labour market effects of spousal education he reported). In light of evidence suggesting that, all else equal, women with educated husbands tend to replace housework with market work at a similar rate to which they replace housework with leisure (Hersh and Stratton 1994), it may be more reasonable to think that women would switch from household work to market work when their husbands are more productive in the household. ${ }^{1}$ The possibility that a woman's labour supply decisions might be affected by her husband's education because education reflects non-market productivity will be referred to throughout the paper as the "productivity hypothesis".

A second explanation for the labour market effects of spousal education derives from the fact that men and women do not match randomly in the marriage market. Many papers have documented the fact that women tend to match with men of the same education level in the United States and that marriages have become more strongly (positively) correlated over the past half-century (Mare 1991; Pencavel 1998; Schwartz and Mare 2005). Other papers have found a similar pattern regarding matching on the basis of income (Schwartz 2010) and claim that changes over time in the shape of the relationship between married women's hours and their husbands' wage levels are driven by the extent of assortative matching on wages (Bredemeier

\footnotetext{
${ }^{1}$ Hersh and Stratton's estimates suggest that having a husband with a post-school education increases weekly leisure time by 1.65 hours, holding work time constant, but (using a reparameterisation) increases weekly labour supply by 1.84 hours, holding leisure constant.
} 
and Juessen 2010). In a similar vein, if a person's preferences regarding the division of labour within the household are correlated (but not perfectly) with his/her education, it might be expected that a woman's choice of husband would reflect her own taste for work, even after controlling for her education level. In this case, even if education confers no productive benefits beyond higher wages, spousal education would be correlated with labour supply. The argument that spousal education simply captures the effects of a woman's own unobserved tastes for work will be termed the "sorting hypothesis".

Finally, it might be the case that spousal education affects a woman's labour supply by altering her preferences for work. It could be that women (or men) change their attitudes to work over time as they are influenced by the views of their spouses. ${ }^{2}$ However, it is equally possible that women base their labour supply decisions in part on their perceptions of their husband's reliability and future labour market prospects. Such attributes are only established over time as a couple learn about each other. Regardless of the reasons underlying a woman's change in work orientation, it is expected that a man's education should not be correlated with his wife's hours at the time of marriage but should have an increasingly large effect as time passes. This argument will be termed the "taste hypothesis".

\section{Model}

This section outlines a model of labour supply among married women, taking into account their and their spouses' wages, education levels and preferences regarding the division of labour within a household. Households are assumed to value both consumption, $C$, and household production, $H$, according to the following utility function:

$$
U=\ln C+\beta \ln H,
$$

where $\beta>0$. Consumption is derived from labour income. The total hours available for each spouse is normalised to be 1 and wives and husbands earn wage rates $w$ and $\bar{w}$, respectively. Each hour spent in the household yields $v$ units of non-market goods,

\footnotetext{
${ }^{2}$ Using the same data on attitudes towards female roles in the household that are discussed in Section 4, Farré and Vella (2007) found considerable persistence in attitudes across generations and a consequent effect on labour supply.
} 
but husbands are assumed to devote all their time to market work. ${ }^{3}$ Household production is also positively related to each spouse's education level. A one-unit increase in wife's education, $e$, or husband's education, $\bar{e}$, raises household production by $\alpha$ units. Equation 1 can therefore by rewritten as:

$$
U=\ln (w n+\bar{w})+\beta \ln (v(1-n)+\alpha(e+\bar{e})),
$$

where $n$ is the wife's hours of market work. Maximising household utility with respect to $n$ yields the following first order condition:

$$
n^{*}= \begin{cases}0 & \text { if } w<\frac{\beta v \bar{w}}{\alpha(e+\bar{e})+v} \\ \frac{1}{1+\beta}\left(\frac{\alpha(e+\bar{e})+v}{v}-\beta \frac{\bar{w}}{w}\right) & \text { if } \frac{\beta v \bar{w}}{\alpha(e+\bar{e})+v} \leq w \leq \frac{\beta v \bar{w}}{\alpha(e+\bar{e})-\beta v} . \\ 1 & \text { if } w>\frac{\beta v \bar{w}}{\alpha(e+\bar{e})-\beta v}\end{cases}
$$

To avoid focusing on corner solutions, the rest of this section shall bound $w$ accordingly. ${ }^{4}$ Since husbands are assumed to spend all their time working, $\beta$ represents the extent of a household's preference for a "traditional" arrangement, wherein the wife spends all her time engaged in household production rather than in market work. ${ }^{5}$ Rather than treat $\beta$ as a constant, it shall be allowed to vary across households and modelled explicitly. It is assumed that a household's value of $\beta$ is determined by the individual preferences of the husband and wife, which are $\hat{\beta}$ and $\hat{\bar{\beta}}$, respectively. Individual preferences are related to a person's education level as well as the quality of his/her marriage, $M$, as follows:

$$
\begin{aligned}
& \hat{\beta}=\mu+\gamma e+\delta M+\varepsilon, \varepsilon \sim U(-\chi, \chi) ; \\
& \hat{\bar{\beta}}=\bar{\mu}+\overline{\gamma \bar{e}}+\delta M+\bar{\varepsilon}, \bar{\varepsilon} \sim U(-\chi, \chi) .
\end{aligned}
$$

The restrictions $\bar{\mu}+\overline{\gamma e}>\mu+\gamma e$ and $\bar{\mu}+\overline{\gamma e}+2 \chi>\mu+\gamma e$ are imposed. The first restriction implies that an average unmarried man has a larger $\hat{\bar{\beta}}$ (i.e. more

\footnotetext{
${ }^{3}$ It is possible to model husbands' work decisions jointly with those of their wives but to restrict wages so that wives only enter the labour market once their husbands have devoted all their time to work, as in Bredemeier and Juessen (2010). This would yield essentially the same predictions as the model presented here.

${ }^{4}$ This simplifies the model; however, since an increase in $\beta$ is negatively related to both hours conditional on working and the probability of working, it does not change the key results presented. The empirical analysis uses tobit estimation to account for the censoring of work hours.

5 The terms “conservative" and "liberal” are used throughout the paper to refer to couples or individuals who favour or disfavour such an arrangement, respectively.
} 
conservative tastes) than an average unmarried woman, regardless of education level. Although this is not necessary, it simplifies the algebra considerably. ${ }^{6}$ The second restriction implies that for any combination of education levels, there are couples that share the same preferences (and hence might marry).

$\varepsilon$ and $\bar{\varepsilon}$ introduce a random component to preferences and allow for the fact that equally-educated women have different tastes because of their backgrounds. It is assumed that $\delta>0$ in Equations 4 and 5, meaning that both spouses prefer a higher degree of intra-household specialisation when they are in a happy and productive marriage (Johnson and Skinner 1986; Papps 2006). Marital quality, $M$, is determined by both the total amount of effort and resources the two spouses have invested in the marriage and by each spouse's assessment of the quality of their match. This is modelled as a function of the education of each spouse and the number of years of marriage, $t$ :

$$
M=\sum_{j=0}^{t}(\pi e+\overline{\pi e})=\pi e t+\overline{\pi e} t .
$$

$M$ is zero at the time of marriage, because newlyweds have had no time to either invest in marriage or to learn about their spouse's suitability as a mate. It is assumed that $\pi>0$ and $\bar{\pi}>0$, so that marital quality is highest for the most highly-educated couples, reflecting the findings that educated people tend to have higher lifetime incomes (Blundell and MaCurdy 1999) and face lower probabilities of divorce (Isen and Stevenson 2010).

Couples are assumed to match perfectly on the basis of their individual preferences, so that $\hat{\beta}=\hat{\bar{\beta}}{ }^{7}$ Since women share their husbands' tastes for specialisation within the household, it is possible to deduce information about the random component of $\hat{\beta}$ from a woman's observed choice of husband. Women who would otherwise be expected to have liberal attitudes, given their education, but who marry men with traditional preferences must have relatively low values of $\varepsilon$ and vice versa. The mean of labour supply conditional on the observable variables can be

\footnotetext{
6 This assumption means that at every education level, the most extremely liberal women and extremely conservative men will be unable to find suitable partners. Figure 1 suggests that this assumption is inappropriate, as the most educated men tend to be more liberal than the least educated women.

${ }^{7}$ It is possible to allow a fraction of couples to match randomly with respect to preferences (Kremer 1997; Bredemeier and Juessen 2010) without changing the main findings in this section.
} 
found by integrating the labour supply function (Equation 3) over $\varepsilon$, taking into account the density of $\varepsilon$ and its restricted range:

$$
\begin{aligned}
& n^{*}= \int_{\varepsilon=\bar{\mu}-\mu+\bar{e}-\gamma e-\chi}^{\chi} \frac{1}{1+\mu+\gamma e+\delta H+\varepsilon}\left(\frac{\alpha(e+\bar{e})+v}{v}-(\mu+\gamma e+\delta H+\varepsilon) \frac{\bar{w}}{w}\right) \\
& \frac{\gamma e-\overline{\gamma e}+\mu-\bar{\mu}+2 \chi}{\gamma} d \varepsilon \\
&=\frac{\ln (1+\mu+\gamma e+\delta(\pi e t+\overline{\pi e} t)+\chi)-\ln (1+\bar{\mu}+\overline{\gamma e}+\delta(\pi e t+\overline{\pi e} t)-\chi)}{\left.\gamma e-\overline{\gamma e}+\mu-\bar{\mu}+2 \chi \quad \frac{\alpha(e+\bar{e})+v}{v}+\frac{\bar{w}}{w}\right)-\frac{\bar{w}}{w} .}
\end{aligned}
$$

\section{Predictions of the different hypotheses}

Equation 7 relates female labour supply to the education of both the husband and wife. The total effect of spousal education on a woman's hours is made up of three separate effects, reflecting the three hypotheses discussed in the previous section. To isolate the individual effects of each channel, it is possible to differentiate Equation 7 with respect to $\bar{e}$ while "closing off" the other two channels. The productivity effect, sorting effect and preference effect can be eliminated by setting $\alpha=0, \gamma=\bar{\gamma}=0$ and $\delta=0$ in turn. The derivatives of hours worked with respect to spousal education under each hypothesis are given below:

1. Productivity hypothesis (setting $\gamma=\bar{\gamma}=0$ and $\delta=0$ ):

$$
\frac{\partial n^{*}}{\partial \bar{e}}=\frac{\alpha}{v} \frac{\ln (1+\mu+\chi)-\ln (1+\bar{\mu}-\chi)}{\mu-\bar{\mu}+2 \chi}>0
$$

Hence, the derivative should always take a constant positive value.

2. Sorting hypothesis (setting $\alpha=0$ and $\delta=0$ ):

$$
\frac{\partial n^{*}}{\partial \bar{e}}=\frac{\bar{\gamma}\left(1+\frac{\bar{w}}{w}\right)}{\gamma e-\overline{\gamma e}+\mu-\bar{\mu}+2 \chi}\left(\ln \frac{1+\mu+\gamma e+\chi}{1+\bar{\mu}+\overline{\gamma e}-\chi}-\frac{1+\mu+\gamma e+\chi}{1+\bar{\mu}+\overline{\gamma e}-\chi}+1\right) \equiv \phi \bar{\gamma},
$$

where $\phi<0$. Hence, the sign of the derivative will be the opposite of the sign of $\bar{\gamma}$.

3. Preference hypothesis (setting $\alpha=0$ and $\gamma=\bar{\gamma}=0$ ):

$$
\frac{\partial n^{*}}{\partial \bar{e}}=\frac{\delta \bar{\pi} t\left(1+\frac{\bar{w}}{w}\right)}{\mu-\bar{\mu}+2 \chi}\left(\frac{1}{1+\mu+\delta(\pi e t+\overline{\pi e} t)+\chi}-\frac{1}{1+\bar{\mu}+\delta(\pi e t+\overline{\pi e} t)-\chi}\right) \equiv \varphi t,
$$

where $\varphi<0$. Hence, the derivative will be zero for newlyweds and become 
proportionally more negative with each subsequent year of marriage.

The three hypotheses therefore generate different predictions regarding the relationship between hours of work among married women and the education of their spouses. Under the productivity hypothesis, a positive relationship should be observed in all time periods and across all types of household. Under the sorting hypothesis, the sign of the relationship depends on how men's preferences regarding their wives working vary by education level. Finally, under the preference hypothesis, spousal education should have no influence on wives' labour supply at the time of marriage but should have an increasingly large negative effect the longer a couple are married.

\section{Data}

In order to produce evidence on the labour supply effects of spousal education, the empirical analysis uses data from two sources: the CPS and the NLSY 1979. The CPS provides representative cross-sectional data over multiple decades and allows a broad analysis of how the relationship between labour supply and spousal education has evolved. In contrast, the NLSY provides longitudinal data on a single cohort of individuals, with more detailed information on flows in and out of marriage and on preferences. A full explanation of how the two datasets were constructed is provided in Appendix 1.

\section{NLSY data}

The NLSY 1979 is a nationally representative sample of 12,686 young men and women who were 14-22 years old when they were first surveyed in $1979 .^{8}$ These individuals were interviewed annually until 1994 and are currently interviewed on a biennial basis. This study uses data for 1979-2008, although to focus on the decisions of prime-aged couples, the labour supply regression samples are restricted to women aged 25-54 (the oldest respondent in the sample is 50) with husbands aged 25-54.

Hourly wages were constructed from the annual earnings and hours worked by a respondent and his/her spouse during the year prior to each interview. All monetary values are expressed in 2000 dollars, using the National Income and Product Account price index for personal consumption expenditures. For those who did not work in a

\footnotetext{
${ }^{8}$ Hence, these women were aged 38-46 at the time Belkin wrote her article in 2003, making them only a few years older than most of the women she interviewed (who were predominantly in their mid-30s).
} 
given year, had missing income or work hours data, received self-employment income or had a wage rate less than $\$ 2$ or greater than $\$ 200$, the wage rate is interpolated. ${ }^{9}$

The own and spouse education variables used in the analysis consist of four dummy variables, capturing whether a person's highest attained level of education was Grade 11 or less, Grade 12, some college but not a degree, or a college degree or higher. These categories were constructed from the NLSY data on highest schooling grade completed, with anyone who reported at least 16 years of schooling assumed to have obtained a college degree.

Other variables that are used in the labour supply regressions include race/ethnicity (only available for the respondent); own and spouse age; percentile score on the Armed Forces Qualification Test (AFQT); family rent, dividend and interest income; Census region of residence; urban status; number of children in household and presence of a child aged under 6 in the household; and whether the respondent is currently attending school.

The NLSY intermittently asked a series of eight questions designed to elicit respondents' attitudes towards the roles of women. In the 1979, 1982, 1987 and 2004 interviews, respondents were asked to evaluate the following statements on a fourpoint scale: "a woman's place is in the home, not in the office or shop", "a wife who carries out her full family responsibilities doesn't have time for outside employment”, “a working wife feels more useful than one who doesn’t hold a job”, “employment of wives leads to more juvenile delinquency”, “employment of both parents is necessary to keep up with the high cost of living”, "it is much better for everyone concerned if the man is the achiever outside the home and the woman takes care of the home and family", "men should share the work around the house with women, such as doing dishes, cleaning and so forth” and "women are much happier if they stay at home and take care of their children”. A response may be coded as 1 (strongly disagree), 2 (disagree), 3 (agree) or 4 (strongly agree).

Figure 1 plots the average response to each question by sex and education level, using data from the survey closest to the year a respondent was 21. Other than Question 3 (on the usefulness of working wives), men consistently display more conservative attitudes than women with the same level of education. More education

\footnotetext{
${ }^{9}$ Imputing missing wage observations using regression models instead made little difference to the results presented in the following section.
} 
Figure 1

Average responses to female roles attitude questions at age 21 by education and sex

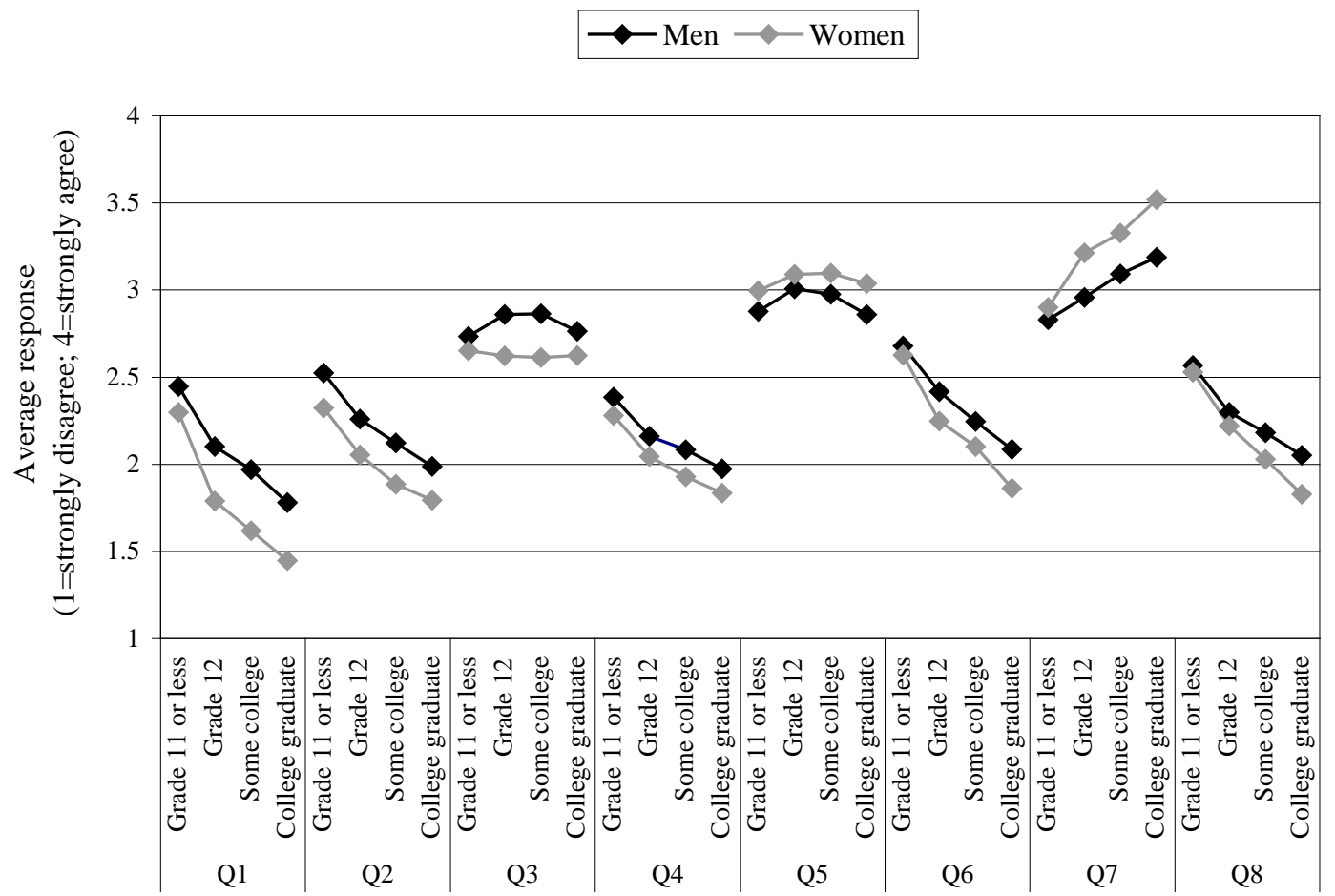

Q1: “A woman's place is in the home, not in the office or shop.”

Q2: “A wife who carries out her full family responsibilities doesn't have time for outside employment.”

Q3: “A working wife feels more useful than one who doesn't hold a job.”

Q4: "Employment of wives leads to more juvenile delinquency."

Q5: "Employment of both parents is necessary to keep up with the high cost of living."

Q6: "It is much better for everyone concerned if the man is the achiever outside the home and the woman takes care of the home and family."

Q7: "Men should share the work around the house with women, such as doing dishes, cleaning and so forth."

Q8: "Women are much happier if they stay at home and take care of their children.”

Notes: The data points represent means across individuals weighted by NLSY sampling weights. A person's response is taken from the survey closest to the year they were aged 21, although they may be as young as 19 or as old as 23 .

is strongly (and monotonically) associated with more liberal responses to all questions, except Questions 3 and 5 (on the need for both parents to work), suggesting that, at least for this cohort, the model parameters $\gamma$ and $\bar{\gamma}$ are both negative.

Means for some of the key variables used in the NLSY labour supply regressions are presented in Table 1. Each observation here represents a person-year combination. The first two columns report means for the married women in the sample; the last two columns report means for the wives of the married men in the sample. Since women tend to marry at younger ages than men, the former sample has a greater average marriage length and a larger fraction of remarried women. 
Table 1

Means for NLSY regression sample

\begin{tabular}{|c|c|c|c|c|}
\hline \multirow[t]{2}{*}{ Variable } & \multicolumn{2}{|c|}{ Married women } & \multicolumn{2}{|c|}{ Wives of married men } \\
\hline & Own value & Spouse value & Own value & Spouse value \\
\hline Annual work hours & 1414.696 & 2155.121 & 1460.269 & 2228.720 \\
\hline Wage (in 2000 dollars) & 15.707 & 18.420 & 13.783 & 22.125 \\
\hline Age & 33.860 & 36.200 & 33.441 & 34.441 \\
\hline Grade 11 or less & 0.042 & 0.111 & 0.072 & 0.061 \\
\hline Grade 12 & 0.451 & 0.440 & 0.411 & 0.498 \\
\hline Some college & 0.287 & 0.241 & 0.283 & 0.219 \\
\hline College graduate & 0.220 & 0.207 & 0.235 & 0.222 \\
\hline Female roles attitude question 1 & 1.710 & - & - & 2.058 \\
\hline Female roles attitude question 2 & 1.985 & - & - & 2.201 \\
\hline Female roles attitude question 3 & 2.633 & - & - & 2.832 \\
\hline Female roles attitude question 4 & 1.985 & - & - & 2.147 \\
\hline Female roles attitude question 5 & 3.125 & - & - & 2.985 \\
\hline Female roles attitude question 6 & 2.167 & - & - & 2.352 \\
\hline Female roles attitude question 7 & 3.299 & - & - & 3.040 \\
\hline Female roles attitude question 8 & 2.131 & - & - & 2.269 \\
\hline Would work if not necessary & 0.776 & - & - & 0.859 \\
\hline Remarried & \multicolumn{2}{|c|}{0.206} & \multicolumn{2}{|c|}{0.165} \\
\hline Years since marriage & \multicolumn{2}{|c|}{9.555} & \multicolumn{2}{|c|}{8.747} \\
\hline Number of observations & \multicolumn{2}{|c|}{25,878} & \multicolumn{2}{|c|}{19,122} \\
\hline
\end{tabular}

Notes: Each observation represents a person-year combination.

The female roles attitude questions are measured at age 21 .

Appendix 1 describes the construction of the dataset.

\section{CPS data}

Data from the March CPS are also used in the next section to estimate the relationship between labour supply and spousal education. To increase the sample size, three years of data were pooled for each decade: 1978-1980, 1988-1990, 19982000 and 2008-2010. For convenience of elucidation, these samples are referred to as “1980”, “1990”, “2000” and "2010”. The CPS sampling weights for the March supplement are used throughout the analysis, adjusted so that each year is weighted equally. As with the NLSY data, data are restricted to married individuals aged 25-54 with a spouse present who is also aged 25-54. Also as in the NLSY, hours worked in the previous year is used as the measure of labour supply, in this case constructed by multiplying usual hours worked per week and weeks worked in the previous year.

Own and spouse's hourly earnings are constructed using wage and salary income in the previous year (again expressed in 2000 dollars using the National Income and Product Account price index) and annual hours worked. Non-labour income is defined as the sum of interest, dividend and rental income. Those with wages less than $\$ 2$ or greater than $\$ 200$, those who worked no hours or were self-employed and those with allocated earnings data are assigned imputed wages, equal to the predicted values 
from a series of wage regressions. Following the approach of Blau and Kahn (2007), separate imputation regressions were run for each combination of sample period, gender and whether a person worked less than 20 weeks (including zero weeks) or 20 or more weeks in the previous year.

The same four categories of education are constructed as in the NLSY sample, with Jaeger's (1997) suggested taxonomy used to assign years of schooling to each person in the 2000 and 2010 samples first, due to changes the CPS made to its education coding scheme.

Although the CPS has not historically recorded whether a person is living with a romantic partner outside of marriage, the Census Bureau's Partners of the Opposite Sex Sharing Living Quarters (POSSLQ) definition provides an imperfect method for identifying such couples (Casper and Cohen 2000). Under POSSLQ, a cohabiting couple exists whenever there is a pair of unrelated adults (aged 15 or over) of the opposite sex living together in a household in which there were no other adults present. This definition was used to create a sample of unmarried cohabitants in each period.

Under the CPS sampling plan, households are interviewed in the same four calendar months in two consecutive years. This means that half of the sample in any year can (theoretically) be matched to the previous year. Using the approach outlined by Madrian and Lefgren (2000), these longitudinal matches were constructed. Only married couples who lived together in two consecutive years will be included in this sample, meaning that newlyweds and divorcing couples will be excluded. However, since the CPS is a survey of dwellings, couples who move house or are temporarily separated will also be excluded from the longitudinally-matched sample.

Table 2 presents means for some of the primary variables in the CPS sample. Hours worked by married women increased sharply in the 1980s, much more gradually in the 1990s and fell slightly in the 2000s. Meanwhile, there was a dramatic increase in education among married women, with the fraction of women with a college degree more than doubling between 1980 and 2010. Although not shown in the table, there has also been a modest increase in the degree of assortative matching of couples by education over the past three decades. In 1980, 53\% of couples had the same education level; by 2010, this had risen to 58\%, with over half the increase occurring during the 2000s. 
Table 2

Means for CPS regression sample

\begin{tabular}{|l|c|c|c|c|}
\hline Variable & $1978-1980$ & $1988-1990$ & $1998-2000$ & $2008-2010$ \\
\hline Annual work hours & 935.072 & 1232.580 & 1357.134 & 1337.841 \\
Wage (in 2000 dollars) & 9.752 & 11.380 & 13.541 & 15.252 \\
Spouse's wage (in 2000 dollars) & 18.678 & 19.159 & 20.071 & 21.531 \\
Age & 37.108 & 37.158 & 38.900 & 39.624 \\
Spouse's age & 39.548 & 39.349 & 40.815 & 41.419 \\
Own education: & & & & \\
Grade 11 or less & 0.198 & 0.123 & 0.085 & 0.077 \\
Grade 12 & 0.475 & 0.441 & 0.334 & 0.264 \\
Some college & 0.166 & 0.208 & 0.283 & 0.279 \\
College graduate & 0.161 & 0.228 & 0.298 & 0.380 \\
Spouse's education: & & & & \\
Grade 11 or less & 0.220 & 0.140 & 0.096 & 0.089 \\
Grade 12 & 0.359 & 0.368 & 0.317 & 0.303 \\
Some college & 0.170 & 0.198 & 0.262 & 0.253 \\
College graduate & 0.251 & 0.294 & 0.325 & 0.355 \\
\hline Number of observations & 60,850 & 58,688 & 49,382 & 72,877 \\
\hline
\end{tabular}

Notes: Means use CPS sampling weights, adjusted so that each year is weighted equally. Appendix 1 describes the construction of the dataset.

\section{Results}

The model presented in Section 3 demonstrates that the three explanations for why spousal education affects labour supply - the productivity hypothesis, sorting hypothesis and preference hypothesis - generate different predictions for the direction of the relationship and how it should vary over time and over the course of a given marriage. In this section, the longitudinal data from the NLSY 1979 and crosssectional data from three decades of the CPS are used to test these predictions.

\section{Results for a single cohort}

To determine whether spousal education has an effect on labour supply among married women, after controlling for own education and wage variables, the following equation for person $i$ in year $t$ (a linearised form of Equation 7) was initially estimated using the NLSY sample: ${ }^{10}$

$$
n_{i t}=a_{0}+a_{1} \ln w_{i t}+a_{2} \ln \bar{w}_{i t}+\sum_{j=2}^{4} a_{3 j} I\left(e_{i}=j\right)+\sum_{j=2}^{4} a_{4 j} I\left(\bar{e}_{i}=j\right)+\mathbf{x}_{i t}^{\prime} \mathbf{a}+u_{i t},
$$

\footnotetext{
${ }^{10}$ Equation 7 conditions on husband's wage but does not take account of his work hours, which is appropriate under the model's assumption that married men devote all their time to market work. In practice, it is possible that women reduce their labour supply when married to men working particularly long hours (Cha 2010). Nevertheless, the results in both the NLSY and CPS analyses are very similar if husband's wage and non-labour income and replaced by the sum of husband's annual wage income and non-wage income.
} 
Table 3

Results for annual hours equation

\begin{tabular}{|c|c|c|c|c|}
\hline \multirow[t]{2}{*}{ Variables } & \multicolumn{3}{|c|}{ Married women } & \multirow{2}{*}{$\begin{array}{c}\text { Wives of } \\
\text { married men } \\
\text { (iv) }\end{array}$} \\
\hline & (i) & (ii) & (iii) & \\
\hline \multicolumn{5}{|l|}{ Own education coefficients } \\
\hline Grade 12 & $\begin{array}{c}565.420^{* * *} \\
(38.438)\end{array}$ & $\begin{array}{c}331.751^{* * *} \\
(39.810)\end{array}$ & $\begin{array}{c}409.659 * * * \\
(38.664)\end{array}$ & $\begin{array}{c}460.319 * * * \\
(30.194)\end{array}$ \\
\hline Some college & $\begin{array}{c}737.455^{* * *} \\
(39.851)\end{array}$ & $\begin{array}{c}557.102^{* * *} \\
(42.219)\end{array}$ & $\begin{array}{c}544.973 * * * \\
(40.994)\end{array}$ & $\begin{array}{c}572.764 * * * \\
(32.210)\end{array}$ \\
\hline College graduate & $\begin{array}{c}842.381 * * * \\
(42.731)\end{array}$ & $\begin{array}{c}676.848 * * * \\
(45.556)\end{array}$ & $\begin{array}{c}637.035 * * * \\
(44.291)\end{array}$ & $\begin{array}{c}628.122 * * * \\
(34.800)\end{array}$ \\
\hline \multicolumn{5}{|c|}{ Spouse education coefficients } \\
\hline Grade 12 & $\begin{array}{c}118.977 * * * \\
(24.389)\end{array}$ & $\begin{array}{c}86.758 * * * \\
(24.420)\end{array}$ & $\begin{array}{c}\text { 71.602*** } \\
(23.684)\end{array}$ & $\begin{array}{c}218.822 * * * \\
(31.809)\end{array}$ \\
\hline Some college & $\begin{array}{c}109.160 * * \\
(26.823)\end{array}$ & $\begin{array}{l}65.979 * * \\
(26.901)\end{array}$ & $\begin{array}{l}43.296 * \\
(26.105)\end{array}$ & $\begin{array}{c}256.617 * * * \\
(34.768)\end{array}$ \\
\hline College graduate & $\begin{array}{c}60.970^{* *} \\
(29.687)\end{array}$ & $\begin{array}{c}34.404 \\
(29.797)\end{array}$ & $\begin{array}{c}22.148 \\
(28.935)\end{array}$ & $\begin{array}{c}241.500^{* * * *} \\
(36.696)\end{array}$ \\
\hline AFQT deciles & No & Yes & Yes & No \\
\hline Child variables & No & No & Yes & No \\
\hline Pseudo R-squared & 0.007 & 0.008 & 0.012 & 0.010 \\
\hline Number of observations & 25,878 & 25,878 & 25,776 & 19,122 \\
\hline
\end{tabular}

Notes: Tobit estimation is used. All models also include controls for own and spouse log wage, household non-labour income, quadratics in own and spouse age and dummy variables for remarriage, school attendance, race/ethnicity (3 categories), region (4 categories), metropolitan area and year (19 categories).

The child variables include number of children in household and presence of a child aged under 6 in the household.

Standard errors are presented in parentheses. *, ** and *** denote significance at the $10 \%, 5 \%$ and $1 \%$ level, respectively.

where $n$ is annual hours worked, $w$ and $\bar{w}$ are own and spouse hourly wage offer, respectively, and the $I(\cdot)$ terms are indicator variables for each level of own or spouse education. As noted in the previous section, four education categories are considered - less than high school, high school graduate, some college, college graduate - and the first of these is used as the reference category. The additional control variables in $\mathbf{x}$ include family non-labour income, quadratics in own and spouse age and dummy variables for remarriage, school attendance, race/ethnicity (3 categories), Census region (4 categories), metropolitan area and year (19 categories).

Table 3 presents the results of tobit estimation of Equation 11. In the first column, spousal education is found to have an inverse U-shaped effect on hours, controlling for own education and own and spouse wages. Relative to those women whose husbands do not have a high school diploma, women whose husbands have Grade 12 work about 120 extra hours each year. Acquiring more education past this point does not result in a man's wife working more. Instead, a woman's annual hours fall by 60 
when her husband has a college degree rather than a school diploma. ${ }^{11}$

If couples tend to match on the basis of underlying skill, spousal education might simply be capturing the effects of a woman's own unobserved ability, after controlling for her education level. This can be addressed with recourse to the woman's score on the AFQT, which was administered during the first round of interviews in 1979. The AFQT assesses a person's aptitude regarding basic mathematics and reading comprehension. Many studies have used this score as a measure of a person's underlying ability (Cawley et al. 2001; Barrow and Rouse 2005). Therefore, a set of dummy variables for a person's AFQT decile are added to the set of control variables in Equation 11, in addition to the own education dummies. As seen in the second column of Table 3, the coefficients on spousal education fall somewhat, so that moving from Grade 12 to a college degree involves only a 52 hour fall in labour supply.

Controls for the presence of dependent children in the household are excluded from the preferred specification, partly because the decision to have children is endogenous to a woman's labour supply behaviour, but also because children reflect an important dimension of a household's (or an individual's) preference for nonmarket production. ${ }^{12}$ Nonetheless, to provide evidence on the extent to which variation in number of children is responsible for the effect of spousal education on hours, controls for the number of children and presence of a child under 6 were added to the model in the third column of Table 3. If an increased preference for household production manifests itself entirely in an increased number of children, the spousal education variables should only reflect the effect of the productivity and sorting hypotheses. Interestingly, while the coefficients on spousal education fall, the effect of a husband moving from Grade 12 to a college degree is almost unchanged.

As an additional robustness check, data for the wives of the men sampled by the NLSY were used instead. While an inverse U-shaped effect of spousal education is

\footnotetext{
${ }^{11}$ Alternative specifications using the probability of working and annual hours conditional on working as measures of labour supply are reported in the first two columns of Table A1. These reveal that different types of labour supply adjustment appear to underlie the inverse U-shaped relationship in Table 3. The positive marginal effect of a husband having Grade 12 is generated by women entering the labour market, while the negative effect beyond Grade 12 is mainly produced by women cutting back on hours.

${ }^{12}$ Indeed, Belkin (2003) noted that maternity leave often provides a convenient route out of an unloved job. As one woman she interviewed put it: “Timing one’s quitting to coincide with a baby is like timing a breakup to coincide with graduation... It's just a whole lot easier than breaking up in the middle of senior year."
} 
again found, the results (reported in the final column of Table 3) indicate that husband's education has no significant effect on hours beyond Grade 12.

The fact that spousal education does not appear to have a monotonic positive effect on women's labour supply in Table 3 is inconsistent with the productivity hypothesis. Under the sorting hypothesis, the sign of the spousal education effect is determined by the direction of the relationship between men's education and their preference for women working in the home. Since Figure 1 indicates that this relationship is monotonically negative, it appears that the sorting hypothesis is also unable to explain the results in Table 3. However, by forcing the effect of spousal education to be the same on all married women, regardless of length of marriage, Equation 11 does not allow the preference hypothesis to be evaluated. In order to do this, the education dummy variables in Equation 11 are interacted by the number of years since marriage, $t$ :

$$
\begin{aligned}
n_{i t}=b_{0}+b_{1} \ln w_{i t}+b_{2} & \ln \bar{w}_{i t}+\sum_{j=2}^{4} b_{3 j} I\left(e_{i}=j\right)+\sum_{j=2}^{4} b_{4 j} I\left(\bar{e}_{i}=j\right)+b_{5} t \\
& +\sum_{j=2}^{4} b_{6 j} I\left(e_{i}=j\right) \times t+\sum_{j=2}^{4} b_{7 j} I\left(\bar{e}_{i}=j\right) \times t+\mathbf{x}_{i t}^{\prime} \mathbf{b}+v_{i t} .
\end{aligned}
$$

When Equation 12 is estimated using tobit estimation in the first column of Table 4, a much different pattern is found from Table 3. Husband's education has a strong positive effect on married women's hours at the time of marriage and the relationship is now monotonic. Over the course of their marriages, however, women tend to withdraw from the labour market, with those women married to college graduates cutting back on hours each year by twice as much as those with husbands who have only a high school diploma. The inverse U-shaped relationship found in Table 3 appears to be the result of a combination of the productivity and/or sorting hypothesis operating across marriages and the preference hypothesis operating over time within marriages. $^{13}$

To illustrate the patterns seen in Table 4, Figure 2 plots the relationship between predicted women's hours and husbands' education at various stages of marriage: among newlyweds, among those at the mean years of marriage (9.56 years) and among those with 20 years of marriage. The left-hand panel sets all variables other

\footnotetext{
${ }^{13}$ A similar pattern is found when the education variables are interacted with a dummy variable for whether a child under 6 is present instead of years since marriage (see the third column of Table A1), suggesting that most of the hours reductions over the course of a marriage occur at child birth.
} 
Table 4

Results for annual hours equation using interacted education measures

\begin{tabular}{|c|c|c|c|c|}
\hline \multirow[t]{2}{*}{ Variables } & \multicolumn{2}{|c|}{ Married women } & \multicolumn{2}{|c|}{ Wives of married men } \\
\hline & $\begin{array}{l}\text { (i) } \\
\text { Tobit }\end{array}$ & $\begin{array}{c}\text { (ii) } \\
\text { Fixed effects }\end{array}$ & $\begin{array}{l}\text { (iii) } \\
\text { Tobit }\end{array}$ & $\begin{array}{c}\text { (iv) } \\
\text { Fixed effects }\end{array}$ \\
\hline \multicolumn{5}{|l|}{ Own education coefficients } \\
\hline Grade 12 & $\begin{array}{l}275.946 * * * \\
(67.446)\end{array}$ & - & $\begin{array}{c}808.049 * * * \\
(52.200)\end{array}$ & - \\
\hline Some college & $\begin{array}{c}438.780 * * * \\
(69.862)\end{array}$ & - & $\begin{array}{l}950.981 * * * \\
(55.124)\end{array}$ & - \\
\hline College graduate & $\begin{array}{l}508.414 * * * \\
(73.720)\end{array}$ & - & $\begin{array}{l}1086.955^{* * *} \\
(58.012)\end{array}$ & - \\
\hline $\begin{array}{l}\text { Grade } 12 \times \text { years since } \\
\text { marriage }\end{array}$ & $\begin{array}{c}14.098 * * * \\
(4.962)\end{array}$ & $\begin{array}{c}3.925 \\
(4.521)\end{array}$ & $\begin{array}{c}-35.830 * * * \\
(4.537)\end{array}$ & $\begin{array}{c}-29.031 * * * \\
(4.052)\end{array}$ \\
\hline Some college $\times$ years & $9.771^{*}$ & -1.760 & $-38.836 * * *$ & $-30.693 * * *$ \\
\hline $\begin{array}{l}\text { College graduate } \times \text { years } \\
\text { since marriage }\end{array}$ & $\begin{array}{c}(5.150) \\
\left(5.856^{* *}\right. \\
(5.54)\end{array}$ & $\begin{array}{c}(4.06 /) \\
0.713 \\
(4.925)\end{array}$ & $\begin{array}{c}-51.131^{* * *} \\
(5.093)\end{array}$ & $\begin{array}{c}-36.197 * * * \\
(4.433)\end{array}$ \\
\hline \multicolumn{5}{|c|}{ Spouse education coefficients } \\
\hline Grade 12 & $\begin{array}{l}125.788 * * * \\
(41.952)\end{array}$ & $\begin{array}{l}-47.177 \\
(68.058)\end{array}$ & $\begin{array}{c}398.485 * * * \\
(53.877)\end{array}$ & - \\
\hline Some college & $\begin{array}{l}274.367 * * * \\
(45.909)\end{array}$ & $\begin{array}{c}55.366 \\
(82.992)\end{array}$ & $\begin{array}{l}434.493 * * * \\
(58.279)\end{array}$ & - \\
\hline College graduate & $\begin{array}{l}305.067 * * * \\
(49.437)\end{array}$ & $\begin{array}{c}56.806 \\
(92.739)\end{array}$ & $\begin{array}{l}589.421 * * * \\
(60.776)\end{array}$ & - \\
\hline $\begin{array}{l}\text { Grade } 12 \times \text { years since } \\
\text { marriage }\end{array}$ & $\begin{array}{l}-4.223 \\
(3.406)\end{array}$ & $\begin{array}{l}-0.323 \\
(2.897)\end{array}$ & $\begin{array}{c}-17.005 * * * \\
(4.634)\end{array}$ & $\begin{array}{l}-2.442 \\
(4.367)\end{array}$ \\
\hline $\begin{array}{l}\text { Some college } \times \text { years } \\
\text { since marriage }\end{array}$ & $\begin{array}{c}-22.454 * * * \\
(3.785)\end{array}$ & $\begin{array}{c}-10.602 * * * \\
(3.161)\end{array}$ & $\begin{array}{c}-17.317 * * * \\
(5.103)\end{array}$ & $\begin{array}{l}-3.762 \\
(4.723)\end{array}$ \\
\hline $\begin{array}{l}\text { College graduate } \times \text { years } \\
\text { since marriage }\end{array}$ & $\begin{array}{c}-30.907 * * * \\
(4.175)\end{array}$ & $\begin{array}{c}-27.177 * * * \\
(3.409)\end{array}$ & $\begin{array}{l}-39.021 * * * \\
(5.312)\end{array}$ & $\begin{array}{c}-29.350 * * * \\
(4.841)\end{array}$ \\
\hline Years since marriage & $\begin{array}{c}-10.402 * * \\
(5.013)\end{array}$ & $\begin{array}{c}2.301 \\
(6.068)\end{array}$ & $\begin{array}{c}42.736 * * * \\
(4.923)\end{array}$ & $\begin{array}{c}73.574^{* * *} \\
(5.652)\end{array}$ \\
\hline AFQT deciles & Yes & No & No & No \\
\hline $\begin{array}{l}\text { (Pseudo) R-squared } \\
\text { Number of observations }\end{array}$ & $\begin{array}{c}0.008 \\
25,878\end{array}$ & $\begin{array}{c}0.009 \\
25,878\end{array}$ & $\begin{array}{c}0.012 \\
19,122\end{array}$ & $\begin{array}{c}0.003 \\
19,122\end{array}$ \\
\hline
\end{tabular}

Notes: Columns (i) and (iii) include the same controls as in Table 3; column (ii) excludes the race/ethnicity variables; column (iv) excludes the age variables, race/ethnicity variables and remarriage dummy.

Column (ii) includes a fixed effect for each person; column (iv) includes a fixed effect for each marriage.

Standard errors are presented in parentheses. *, ** and *** denote significance at the $10 \%, 5 \%$ and $1 \%$ level, respectively.

than spousal education equal to their sample means. The upward-sloping curve at the time of marriage flattens over time and gives way to an inverse U-shaped relationship. Although the slope of the curve is rather flat at the mean length of marriage (reflecting the weak results in Table 3), a highly significant downward slope is found above Grade 12 after 20 years of marriage. Since most women tend to marry men with the same education level (and the degree of assortative mating has increased over time), it is useful to consider the effects on labour supply of changing the education of 
Figure 2

Predicted annual hours by spousal education level at different stages of marriage

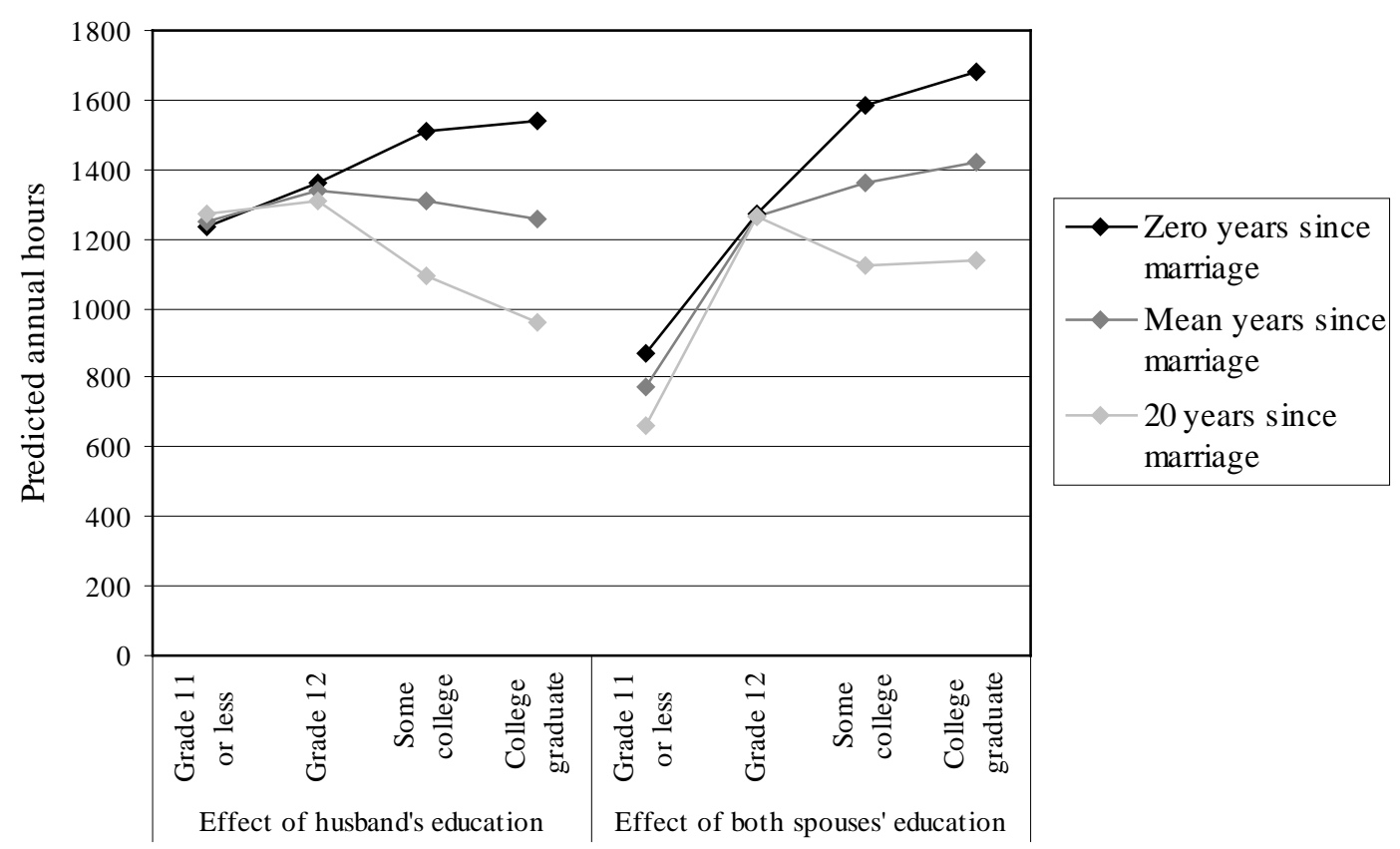

Notes: The data points are the predicted annual work hours from the first column of Table 4, holding all other variables equal to their means across all married women in the sample.

In the left-hand panel, women's education is set equal to its mean for married women in the full sample; in the right-hand panel, women's education is set equal to that of their husbands.

both spouses. In the right-hand panel, women's education is set equal to their husbands'. A stronger upward-sloping relationship is found among newlyweds, although again hours decline over time at the top end, until after 20 years women's hours are significantly lower in college-educated couples than in couples with Grade 12 only.

When fixed effects estimation of Equation 12 is used in the second column of Table 4, the negative effect of the interacted spousal education variables remains, but the main effects are spousal education become insignificant. In the presence of person fixed effects, the coefficients on the main effects are identified only by women with multiple marriages, so the results indicate that a given woman works no less if she marries a man with more education than her previous husband. This runs counter to the predictions of the productivity hypothesis, suggesting that the positive main effect of spousal education found in the first column is principally due to the sorting hypothesis. ${ }^{14}$ The final two columns of Table 4 repeat the tobit and fixed effects

\footnotetext{
${ }^{14}$ This assumes that the random component of preferences, $\varepsilon$, is constant over time for each woman.
} 
specifications for the sample of women married to men in the NLSY sample. In contrast to Table 3, the results for spousal education are now qualitatively the same as those for the women who were surveyed. ${ }^{15}$

Rather than simply being gradual reductions in work hours over time, postmarriage withdrawals of women from the labour market are likely to coincide with the birth of a child. To examine whether the results in Table 4 are driven solely by fertility decisions, own and spousal education are interacted with whether a child under 6 is present in the household in the third column of Table A1. While the own education interaction terms are insignificant, women are found to cut back on hours more at child birth when they have educated husbands. Nonetheless, in the final column of Table A1 it is seen that, even controlling for the interacted child variables, the interaction of spousal education and years since marriage continues to have a significant negative effect on work hours. Hence, childless women also reduce hours over time when they are married to college-educated men.

\section{Results for attitudes towards female roles}

The results reported in Table 4 are consistent with the preference hypothesis operating alongside either the productivity or sorting hypothesis. To further distinguish between these explanations, Equations 4 and 5 are estimated directly, using the female roles attitudes data to proxy a person's value of the preference parameter, $\hat{\beta}$ or $\hat{\bar{\beta}} \cdot{ }^{16}$ Since the attitudes questions were asked multiple times, it is possible to discern how a given woman's tastes evolve over the course of her marriage. Under the productivity hypothesis, preferences should never be systematically related to spousal education; under the sorting hypothesis, preference for a traditional household arrangement should be negatively related to spousal education at the time of marriage, but constant throughout a marriage; under the taste hypothesis, preferences should not be related to spousal education at the time of marriage, but should become increasingly conservative over time for those with the most educated spouses.

\footnotetext{
${ }^{15}$ There is no main effect for spousal education in the final column of Table 4 because the spouses of survey respondents are not followed after divorce. Hence, only marriage-specific (not person-specific) fixed effects may be added.

${ }^{16}$ Using either Equation 4 or 5 to find the mean of household preference in the face of perfect sorting reveals that $\hat{\beta}=\hat{\bar{\beta}}=(\mu+\bar{\mu}+\gamma e+\overline{\gamma e}) / 2+\delta \pi e t+\delta \overline{\pi e} t$.
} 
Table 5

Results for preference equation

\begin{tabular}{|c|c|c|c|c|}
\hline \multirow[t]{2}{*}{ Variables } & \multicolumn{2}{|c|}{ Married women } & \multicolumn{2}{|c|}{ Married men } \\
\hline & $\begin{array}{l}\text { (i) } \\
\text { OLS }\end{array}$ & $\begin{array}{c}\text { (ii) } \\
\text { Fixed effects }\end{array}$ & $\begin{array}{l}\text { (iii) } \\
\text { OLS }\end{array}$ & $\begin{array}{c}\text { (iv) } \\
\text { Fixed effects }\end{array}$ \\
\hline \multicolumn{5}{|l|}{ Own education coefficients } \\
\hline Grade 12 & $\begin{array}{c}-0.472 * * * \\
(0.099)\end{array}$ & - & $\begin{array}{c}-0.604^{* * *} \\
(0.108)\end{array}$ & - \\
\hline Some college & $\begin{array}{c}-0.711^{* * *} \\
(0.105)\end{array}$ & - & $\begin{array}{c}-0.823 * * * \\
(0.124)\end{array}$ & - \\
\hline College graduate & $\begin{array}{c}-0.818^{* * *} \\
(0.120)\end{array}$ & - & $\begin{array}{c}-0.890 * * * \\
(0.141)\end{array}$ & - \\
\hline Grade $12 \times$ years since & -0.028 & 0.005 & $0.051 * *$ & 0.037 \\
\hline Some college $\times$ years & $-0.053 * * *$ & $\begin{array}{l}(0.022) \\
-0.013\end{array}$ & $\begin{array}{l}(0.026) \\
0.073 * *\end{array}$ & $\begin{array}{l}(0.027) \\
0.065^{*}\end{array}$ \\
\hline since marriage & $(0.020)$ & $(0.024)$ & $(0.031)$ & $(0.034)$ \\
\hline College graduate $\times$ years & -0.038 & 0.001 & 0.051 & $0.089 * *$ \\
\hline since marriage & $(0.026)$ & $(0.030)$ & $(0.037)$ & $(0.041)$ \\
\hline \multicolumn{5}{|c|}{ Spouse education coefficients } \\
\hline Grade 12 & $\begin{array}{l}-0.047 \\
(0.069)\end{array}$ & $\begin{array}{c}0.334 \\
(0.209)\end{array}$ & $\begin{array}{l}-0.073 \\
(0.088)\end{array}$ & $\begin{array}{l}-0.301 \\
(0.272)\end{array}$ \\
\hline Some college & $\begin{array}{c}-0.174 * * \\
(0.080)\end{array}$ & $\begin{array}{l}-0.163 \\
(0.249)\end{array}$ & $\begin{array}{c}-0.264 * * \\
(0.103)\end{array}$ & $\begin{array}{l}-0.485 \\
(0.313)\end{array}$ \\
\hline College graduate & $\begin{array}{c}-0.074 \\
(0.097)\end{array}$ & $\begin{array}{c}0.062 \\
(0.293)\end{array}$ & $\begin{array}{c}-0.450 * * * \\
(0.125)\end{array}$ & $\begin{array}{c}-0.752 \\
(0.704)\end{array}$ \\
\hline Grade $12 \times$ years since & 0.002 & 0.007 & $-0.039 *$ & -0.035 \\
\hline marriage & $(0.015)$ & $(0.017)$ & $(0.023)$ & $(0.027)$ \\
\hline Some college $\times$ years & $0.031^{*}$ & $0.036^{*}$ & -0.013 & 0.008 \\
\hline since marriage & $(0.017)$ & $(0.020)$ & $(0.028)$ & $(0.032)$ \\
\hline College graduate $\times$ years & $0.049 * *$ & 0.039 & -0.021 & -0.030 \\
\hline since marriage & $(0.023)$ & $(0.026)$ & $(0.036)$ & $(0.041)$ \\
\hline Years since marriage & $\begin{array}{l}0.044 * * \\
(0.017)\end{array}$ & $\begin{array}{l}-0.027 \\
(0.024)\end{array}$ & $\begin{array}{c}0.003 \\
(0.024)\end{array}$ & $\begin{array}{l}-0.038 \\
(0.037)\end{array}$ \\
\hline R-squared & 0.124 & 0.008 & 0.153 & 0.037 \\
\hline Number of observations & 3,209 & 3,209 & 1,977 & 1,977 \\
\hline
\end{tabular}

Notes: The dependent variable is an index for attitudes towards female roles, as described in text (larger values indicate a more conservative attitude).

Columns (i) and (iii) also include quadratics in own and spouse age and dummy variables for Catholic, Baptist, other Protestant and frequent attendance at religious services; columns (ii) and (iv) exclude the religion variables.

Standard errors are presented in parentheses. *, ** and *** denote significance at the $10 \%, 5 \%$ and $1 \%$ level, respectively.

In order to obtain an overall score of a person's preference for women working, factor analysis was used to form a single factor from the eight questions in the dataset. ${ }^{17}$ Questions 3, 5 and 7 load negatively on the factor, while the others load positively, indicating that a high factor score indicates a preference for a traditional household arrangement. The first column of Table 5 reports the results when the factor is regressed on the own and spouse education variables and the interaction of these with years of marriage. To control for other possible sources of variation in

\footnotetext{
${ }^{17}$ The iterated principal factor method was used, with separate specifications for men and women.
} 
preferences, quadratics in own and spouse age are added, along with dummies for whether the person is Catholic, Baptist or a member of another Protestant denomination (other or no religion is the reference category) and a dummy for whether the person frequently attends religious services. The regression uses the 1979, 1982 and 1987 attitudes data, but excludes the 2004 data in order to focus on the first few years of marriage, when preferences change most in direct response to marriage.

There is some evidence that women who marry educated men tend to be more liberal at the time of marriage (consistent with the sorting hypothesis), although newlywed women whose husbands have college degrees tend to be slightly more conservative than those women whose husbands attended college but have no degree. There is also evidence that all women become more conservative with each year of marriage, but that the effect is largest for women with college-educated husbands. The interaction terms remain marginally significant when person fixed effects are added in the second column of Table 5, however the main effect of spousal education is now insignificant. Since the main effect is identified solely by women remarrying men of different education levels in the fixed effects specification, this indicates that spousal education has no causal effect on preferences at the time of marriage, consistent with the sorting hypothesis.

The final two columns of Table 5 repeat the regressions using the data on attitudes towards female roles for the men in the NLSY sample. Under the assumptions of the model presented in Section 3, preferences should always be the same for a husband and wife; therefore the results are expected to be similar to those for married women. In the model without person effects, a strong negative relationship is found between preferences and both own and spouse education at the time of marriage. This disappears in the fixed effects specification. Regardless of whether person effects are included, highly educated men are found to become increasingly conservative the longer they are married. Education of wives has no effect on the rate at which men's preferences change. These results are all consistent with the sorting and preference hypotheses, but not the productivity hypothesis.

Overall, the specifications in Table 5 suggest that men's education, but not women's education, determines the preferences married couples have regarding 
Table 6

Results for annual hours equation using cross-sectional data

\begin{tabular}{|c|c|c|c|c|}
\hline Variables & $1978-1980$ & $1988-1990$ & $1998-2000$ & $2008-2010$ \\
\hline \multicolumn{5}{|l|}{ Own education coefficients } \\
\hline Grade 12 & $\begin{array}{c}330.353 * * * \\
(16.217)\end{array}$ & $\begin{array}{c}387.528 * * * \\
(17.291)\end{array}$ & $\begin{array}{c}422.536 * * * \\
(23.417)\end{array}$ & $\begin{array}{c}466.999 * * * \\
(21.524)\end{array}$ \\
\hline Some college & $\begin{array}{c}363.639 * * * \\
(20.985)\end{array}$ & $\begin{array}{l}444.45^{* * *} \\
(20.110)\end{array}$ & $\begin{array}{c}530.060^{* * *} \\
(24.937)\end{array}$ & $\begin{array}{c}556.365^{* * *} \\
(22.591)\end{array}$ \\
\hline College graduate & $\begin{array}{c}533.644 * * * \\
(23.413)\end{array}$ & $\begin{array}{c}494.550 * * * \\
(21.853)\end{array}$ & $\begin{array}{c}650.860 * * * \\
(27.149)\end{array}$ & $\begin{array}{c}631.068 * * * \\
(24.218)\end{array}$ \\
\hline \multicolumn{5}{|c|}{ Spouse education coefficients } \\
\hline Grade 12 & $\begin{array}{c}26.216 \\
(16.065)\end{array}$ & $\begin{array}{c}91.445^{* * *} \\
(16.463)\end{array}$ & $\begin{array}{c}146.827 * * * \\
(21.867)\end{array}$ & $\begin{array}{c}154.918 * * * \\
(19.617)\end{array}$ \\
\hline Some college & $\begin{array}{l}-12.753 \\
(19.641)\end{array}$ & $\begin{array}{c}83.765 * * * \\
(18.857)\end{array}$ & $\begin{array}{c}119.195 * * * \\
(23.397)\end{array}$ & $\begin{array}{c}145.396 * * * \\
(20.977)\end{array}$ \\
\hline College graduate & $\begin{array}{c}-138.753 * * * \\
(20.686)\end{array}$ & $\begin{array}{c}-58.823 * * * \\
(19.872)\end{array}$ & $\begin{array}{c}-100.546^{* * * *} \\
(25.226)\end{array}$ & $\begin{array}{l}-30.626 \\
(22.415)\end{array}$ \\
\hline $\begin{array}{l}\text { Pseudo R-squared } \\
\text { Number of observations }\end{array}$ & $\begin{array}{c}0.009 \\
60,850\end{array}$ & $\begin{array}{c}0.010 \\
58,688\end{array}$ & $\begin{array}{c}0.008 \\
49,382\end{array}$ & $\begin{array}{c}0.009 \\
72,877\end{array}$ \\
\hline
\end{tabular}

Notes: Tobit estimation is used. All models also include controls for own and spouse log wage, household non-labour income, quadratics in own and spouse age and dummy variables for own and spouse race/ethnicity (4 categories), region (9 categories), metropolitan area and year (3 categories).

Standard errors are presented in parentheses. *, ** and *** denote significance at the $10 \%, 5 \%$ and $1 \%$ level, respectively.

household specialisation. ${ }^{18}$ The regression results are also consistent with the findings of Srinivas (2007), who compared the 1987 and 2004 attitudes data and found that educated men and women tended to become more conservative over time and that such a shift in attitudes was associated with lower earnings growth for women.

\section{Results for multiple cohorts}

A limitation of the NLSY is that it only provides information on a single cohort. In order to examine whether the relationship between work hours and spousal education has changed over past decades, it is necessary to use repeated crosssectional data. Accordingly, Table 6 reports the results of tobit estimation of Equation 11 using the four CPS samples described in the previous section. Due to data availability, the dummy variables for remarriage, school attendance and AFQT decile are now dropped from the set of control variables; however, dummy variables for spouse's race/ethnicity (which was not recorded in the NLSY) are now added and

\footnotetext{
${ }^{18}$ Therefore, in the model $\bar{\pi}$ is positive but $\pi$ is zero. This result is especially strong when the response to Question 8 (about the happiness of stay-at-home mothers) is used instead of the factor score.
} 
more detailed classifications of race/ethnicity and region are used. ${ }^{19}$

A woman's own education level is found to have a positive effect on her hours in every time period. Having a husband with a high school diploma raises women's work hours, although further increases in spousal education result in fewer hours, echoing the pattern found with the NLSY data (in Table 3). Raising a husband's education from Grade 12 to college degree resulted in his wife working 165 fewer hours per year in 1980. This amount rose to 247 in 2000, before falling back to 189 hours in 2010. Although not reported, the results are robust to the inclusion of controls for number and age of dependent children. ${ }^{20}$

To illustrate how the labour market effects of spousal education have evolved over time, Figure 3 plots the predicted work hours for each period from the regressions in Table 6. The solid black line holds every variable except spouse education constant at its mean value over the full sample. Changes in the other coefficients in the model were responsible for a large upward shift in labour supply during the 1980s and a slight decrease in the 2000s. To examine the effects of assortative matching, the dashed black line in Figure 3 plots predicted women's hours when both spouses are equally educated. After 1990, there is a notable downturn in the hours schedule among college graduates, since the marginal increase in hours resulting from a woman having a college degree is outweighed by the decrease in hours resulting from her spouse having a college degree. The coefficients in Table 6 suggest that this college labour supply penalty has been relatively stable over the past two decades, at around 90-100 hours.

Figure 3 shows that changes in the shape of the relationship between hours and spousal education did not contribute to the decline in women's labour supply in the 2000s. This is confirmed by a Oaxaca decomposition of changes in annual hours over the periods 1980-1990, 1990-2000 and 2000-2010 (reported in Table A3). However, according to the decomposition, the shift towards more educated (and better-paid) spouses did contribute somewhat to the reduction in hours seen during the 2000s.

\footnotetext{
${ }^{19}$ Using own and spouse deciles in the wage distribution rather than log wages, in order to allow a more flexible relationship between labour supply and market productivity, was found to have little effect on the results for spousal education in any of the CPS models.

${ }^{20}$ The result is driven completely by hours adjustment among workers, with spousal education having no effect in a labour force participation probit model. This is consistent with Antecol's (2010) finding that educated women have increasingly cut back on hours after child birth but not withdrawn from the labour market at a greater rate than in previous periods.
} 
Figure 3

Predicted annual hours by spousal education level for married and cohabiting women

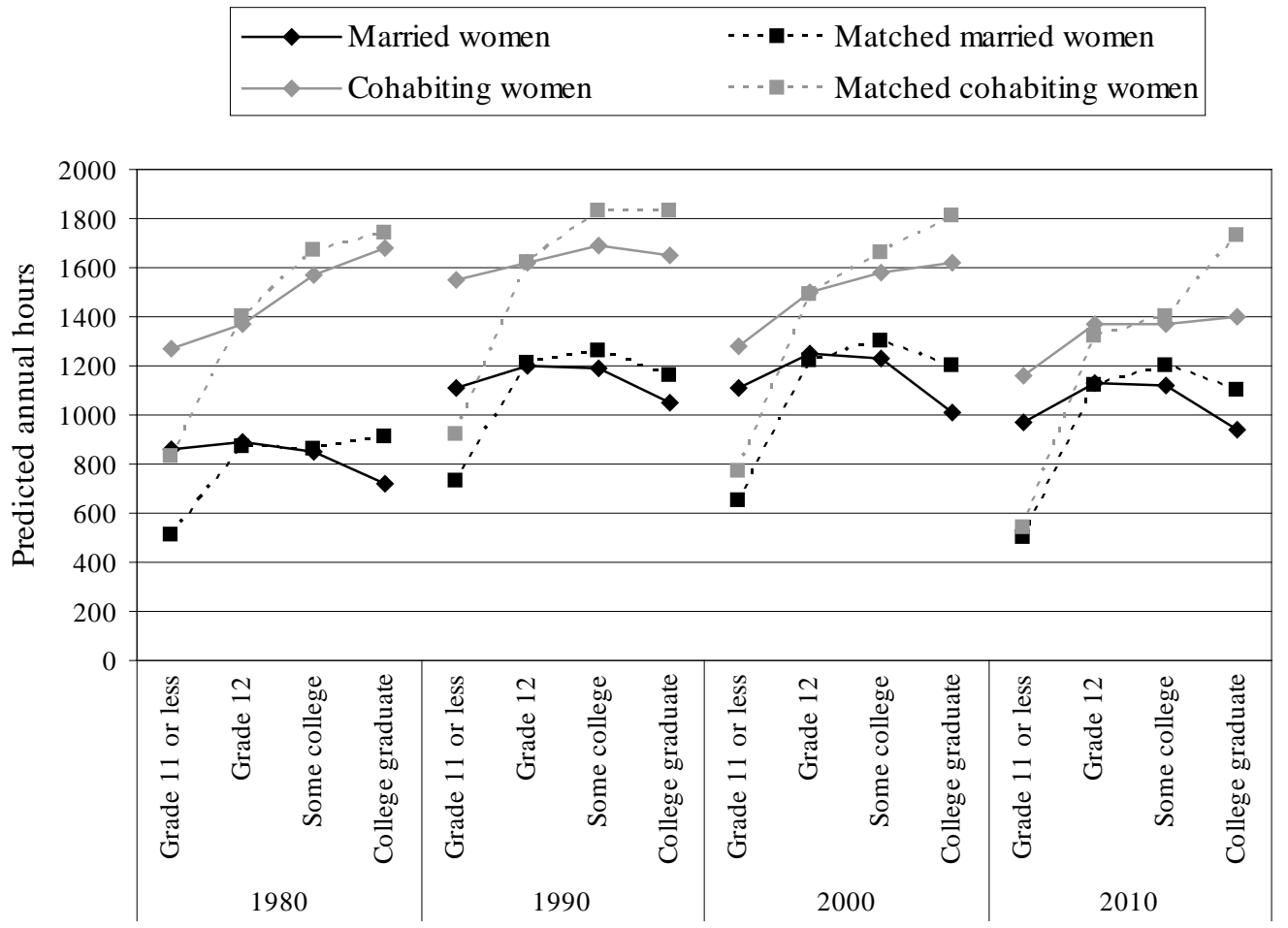

Notes: The data points are the predicted annual work hours from Tables 6 (for married women) and 7 (for cohabitants), holding all other variables equal to their means across all married women in the full sample.

In the matched series, women's education is set equal to that of their husbands; in the other series, women's education is set equal to its mean for married women in the full sample.

Increases in women's own education and wage levels during the 2000s were predicted to lead to higher hours.

A criticism of the regressions in Table 6 is that since the prevalence of marriage has fallen over the past thirty years, the sample of married women in 2010 is more highly selected than the 1980 sample. This will produce biased estimates if unobserved determinants of a woman's propensity to marry are correlated with her work orientation. One method of correcting for this is to remove those women from the earlier samples who would be unlikely to marry in $2010 .{ }^{21}$ Following Blau and Kahn (2007), married women are ranked by their estimated probability from a probit model for selection into marriage, separately for the 1980, 1990 and 2000 samples. Own age, education, race/ethnicity, region and city status are used as explanatory

\footnotetext{
${ }^{21}$ An alternative method of correcting for selection into marriage is to add unmarried cohabitants to the sample of married women, so that all cohabiting couples are included in each period, regardless of marital status. This was also found to have little effect on the results for spousal education.
} 
Table 7

Results for annual hours equation for unmarried cohabiting women

\begin{tabular}{|c|c|c|c|c|}
\hline Variables & $1978-1980$ & $1988-1990$ & $1998-2000$ & $2008-2010$ \\
\hline \multicolumn{5}{|l|}{ Own education coefficients } \\
\hline Grade 12 & $\begin{array}{c}477.149 * * * \\
(100.911)\end{array}$ & $\begin{array}{c}629.777 * * * \\
(59.376)\end{array}$ & $\begin{array}{c}501.363^{* * * *} \\
(60.690)\end{array}$ & $\begin{array}{c}576.245^{* * * *} \\
(56.488)\end{array}$ \\
\hline Some college & $\begin{array}{c}550.273^{* * *} \\
(116.905)\end{array}$ & $\begin{array}{c}\text { 773.669*** } \\
(69.946)\end{array}$ & $\begin{array}{c}590.168^{* * *} \\
(64.239)\end{array}$ & $\begin{array}{c}641.884^{* * *} \\
(59.158)\end{array}$ \\
\hline College graduate & $\begin{array}{c}507.245^{* * *} \\
(126.316) \\
\end{array}$ & $\begin{array}{c}806.670 * * * \\
(79.161)\end{array}$ & $\begin{array}{c}695.518 * * * \\
(73.583)\end{array}$ & $\begin{array}{c}953.305^{* * *} \\
(65.735) \\
\end{array}$ \\
\hline \multicolumn{5}{|c|}{ Spouse education coefficients } \\
\hline Grade 12 & $\begin{array}{l}100.431 \\
(97.430)\end{array}$ & $\begin{array}{c}65.196 \\
(53.963)\end{array}$ & $\begin{array}{c}219.329 * * * \\
(56.805)\end{array}$ & $\begin{array}{c}205.495^{* * * *} \\
(51.954)\end{array}$ \\
\hline Some college & $\begin{array}{c}296.456 * * * \\
(110.746)\end{array}$ & $\begin{array}{c}131.997 * * \\
(63.526)\end{array}$ & $\begin{array}{c}297.125 * * * \\
(62.669)\end{array}$ & $\begin{array}{c}213.452 * * * \\
(56.354)\end{array}$ \\
\hline College graduate & $\begin{array}{c}408.955^{* * *} \\
(112.013)\end{array}$ & $\begin{array}{l}100.468 \\
(70.447)\end{array}$ & $\begin{array}{c}341.974 * * * \\
(69.398)\end{array}$ & $\begin{array}{c}237.301^{* * *} \\
(62.269)\end{array}$ \\
\hline Pseudo R-squared & $\begin{array}{c}0.009 \\
981\end{array}$ & $\begin{array}{l}0.013 \\
2690\end{array}$ & $\begin{array}{l}0.011 \\
3733\end{array}$ & $\begin{array}{l}0.010 \\
5986\end{array}$ \\
\hline
\end{tabular}

Notes: Tobit estimation is used. All models include the same controls as in Table 6.

Standard errors are presented in parentheses. *, ** and *** denote significance at the $10 \%, 5 \%$ and $1 \%$ level, respectively.

variables in the probit models. A fraction of the highest ranked married women are then selected for the regression sample, ensuring that in each period the proportion of all women who are chosen is equal to the proportion of married women in 2010. The results from this restricted sample are presented in Table A2. The selection correction is seen to have little effect on the coefficients on spousal education.

Table 7 presents the results of estimating Equation 11 for the sample of unmarried cohabitants. A striking result here is that partner's education has a monotonic positive effect on hours, even controlling for own education (except at the college level in 1990). The grey lines in Figure 3 plot the predicted hours for the cohabitant sample in each period, while everything except education is held equal at its average value across the sample of married women. Again, the solid line allows only partner's education to vary, while the dashed line sets own education equal to partner's education. Unmarried women living with a partner work more than equally-educated married women, although the gap has closed considerably over the past three decades. The relationship between hours and partner's education also flattened between 1980 and 2010 to more closely reflect the situation for married couples. ${ }^{22}$

\footnotetext{
${ }^{22}$ Both observations presumably reflect the fact that many women who would previously have married now choose to live together outside marriage, so that the cohabitant sample increasingly resembles the married sample.
} 
Compared to married couples, unmarried cohabiting couples are more likely to break up, to be in the early stages of a relationship and to have unstable employment histories (Seltzer 2000; Oppenheimer 2003). These facts suggest that the preference hypothesis is likely to operate more weakly on unmarried couples, which is consistent with the observation that labour supply is always positively related to partner's education among this sample.

To obtain explicit evidence about the effects of the preference hypothesis among married women, the coefficients on the education variables would ideally be allowed to vary with length of marriage, as in Equation 12. Since the CPS did not consistently include information on years since marriage, it is impossible to estimate Equation 12 directly with this dataset. However, by adding and subtracting $n_{i(t-1)}$ from the righthand side of Equation 12, the following equation is generated:

$$
\begin{array}{r}
n_{i t}=b_{5}+n_{i(t-1)}+b_{1} \Delta \ln w_{i t}+b_{2} \Delta \ln \bar{w}_{i t}+\sum_{j=2}^{4} b_{6 j} I\left(e_{i}=j\right) \\
+\sum_{j=2}^{4} b_{7 j} I\left(\bar{e}_{i}=j\right) \\
+\Delta \mathbf{x}_{i t}^{\prime} \mathbf{b}+\Delta v_{i t},
\end{array}
$$

where $\Delta$ represents the change in a variable from $t-1$ to $t$. The only spousal education variables in Equation 13 capture the effects of the preference hypothesis (the $b_{7}$ coefficients). Since hours worked in the previous year is available in the longitudinally-matched CPS sample described in the previous section, this equation may be estimated.

Table 8 reports the results of tobit estimation of Equation 13, where a woman's work hours from the previous year's survey is treated as an offset term (that is, it is entered as a regressor with a coefficient constrained to be 1). While women of all education levels tend to cut back on hours the longer they are married, collegeeducated women reduce their labour supply the least. Although having a husband with less than Grade 12 is associated with the most rapidly declining labour supply after 1990, a negative relationship between hours growth and spousal education is always found past Grade 12. In 1980, women's hours were found to decline more slowly over time among couples where both spouses have a college degree than among couples where both spouses have only some college education. By 1990 this situation had reversed and in 2000 the hours penalty associated with a college degree almost tripled, consistent with Belkin's (2003) argument. However, this was solely due to the effects of husbands' education: the marginal effect of a woman having a college 
Table 8

Results for annual hours equation with offset lag hours

\begin{tabular}{|c|c|c|c|c|}
\hline Variables & $1978-1980$ & $1988-1990$ & $1998-2000$ & $2008-2010$ \\
\hline \multicolumn{5}{|l|}{ Own education coefficients } \\
\hline Grade 12 & $\begin{array}{c}147.034^{* * *} \\
(22.839)\end{array}$ & $\begin{array}{c}137.516 * * * \\
(24.873)\end{array}$ & $\begin{array}{l}56.991 * \\
(33.794)\end{array}$ & $\begin{array}{c}148.284 * * * \\
(36.754)\end{array}$ \\
\hline Some college & $\begin{array}{c}152.491 * * * \\
(29.175)\end{array}$ & $\begin{array}{l}171.831^{* * *} \\
(28.010)\end{array}$ & $\begin{array}{c}93.265^{* * *} \\
(35.096)\end{array}$ & $\begin{array}{c}209.497 * * * \\
(37.687)\end{array}$ \\
\hline College graduate & $\begin{array}{c}224.429 * * * \\
(31.798)\end{array}$ & $\begin{array}{c}192.496 * * * \\
(29.201)\end{array}$ & $\begin{array}{c}155.548 * * * \\
(36.631)\end{array}$ & $\begin{array}{c}259.547^{* * *} \\
(38.632) \\
\end{array}$ \\
\hline \multicolumn{5}{|c|}{ Spouse education coefficients } \\
\hline Grade 12 & $\begin{array}{c}-46.643 * * \\
(22.207)\end{array}$ & $\begin{array}{c}33.742 \\
(23.201)\end{array}$ & $\begin{array}{l}\text { 76.860** } \\
(31.177)\end{array}$ & $\begin{array}{c}117.073 * * * \\
(32.293)\end{array}$ \\
\hline Some college & $\begin{array}{c}-6.906 \\
(27.015)\end{array}$ & $\begin{array}{c}10.851 \\
(25.951)\end{array}$ & $\begin{array}{l}60.993 * \\
(32.413)\end{array}$ & $\begin{array}{c}92.548 * * * \\
(33.845)\end{array}$ \\
\hline College graduate & $\begin{array}{l}-62.898 * * \\
(15.132)\end{array}$ & $\begin{array}{l}-19.366 \\
(26.472)\end{array}$ & $\begin{array}{l}-28.291 \\
(33.631)\end{array}$ & $\begin{array}{c}18.296 \\
(34.701)\end{array}$ \\
\hline $\begin{array}{l}\text { Pseudo R-squared } \\
\text { Number of observations }\end{array}$ & $\begin{array}{c}0.001 \\
13,103\end{array}$ & $\begin{array}{c}0.000 \\
13,520\end{array}$ & $\begin{array}{c}0.001 \\
11,739\end{array}$ & $\begin{array}{c}0.001 \\
11,683\end{array}$ \\
\hline
\end{tabular}

Notes: Tobit estimation is used. All models also include annual hours in the previous year as an offset term along with controls for annual changes in own and spouse log wage and household nonlabour income and dummy variables for year (2 categories).

Standard errors are presented in parentheses. *, ** and *** denote significance at the $10 \%, 5 \%$ and $1 \%$ level, respectively.

degree is a 50 hour gain in labour supply, but this is more than offset by the 74 hour fall in hours associated with having a husband with a college degree. ${ }^{23}$

The results in Table 8 are broadly consistent with the predictions of the preference hypothesis - women reduce their work hours most rapidly during marriage when their husband is most educated. Furthermore, they suggest that this effect has become more pronounced since 2000. Since much of the decline in labour supply during marriage is likely to occur when women give birth, the education variables in Equation 11 are interacted by a dummy variable for whether a dependent child of either spouse aged under 6 is present. The estimated results (presented in Table A4) largely reinforce those in Table 8. Women whose husbands have a college degree reduce their work hours by more when they have young children compared to women whose husbands only have some college education. This child penalty grew from 59 hours in 1980 to 203 hours in 2000, before falling back slightly to 165 hours in 2010. In contrast, there is no evidence that educated women cut back their hours when they have a young child any more than other women do.

\footnotetext{
${ }^{23}$ As noted earlier, the results in Table 6 indicate that the overall college hours penalty has been roughly constant from 1990, suggesting that the magnitude of the effects arising from the productivity or sorting hypotheses must have also changed over time.
} 


\section{Conclusion}

Textbook models of labour supply within households typically assume that the wage rates of both spouses play key roles in a married woman's decision of how much to work. Women's education is also likely to influence their labour supply as it reflects differences in lifetime income or wealth. However, even after controlling for all these factors, a married woman's labour supply might be affected by her husband's education. In this paper, three possible hypotheses are put forward to explain why a man's education could exert an influence on his wife's work hours. Data for a single cohort of married women from the NLSY 1979 indicate that, all else equal, women work more at the time of marriage when their husbands are highly educated. However, over time, the wives of educated men reduce their hours more rapidly than other women. Cross-sectional data from the CPS for 1980-2010 support the latter finding and suggest that the hours penalty associated with a college-educated husband has increased since 1990.

Questions on individuals' attitudes towards gender roles in the NLSY provide a measure of their preference for a traditional division of labour within the household. These data suggest that women with more educated husbands tend to be more liberal at the time of marriage, but become increasingly conservative over the course of their marriages. Overall, the results are consistent with the presence of assortative matching on the basis of preferences as well as tastes for traditional household roles that are related to marital quality. Little support is found for the argument that spousal education measures a husband's non-market productivity.

\section{References}

Antecol, H. (2010). The opt-out revolution: A descriptive analysis. Discussion Paper No. 5089, IZA, Bonn.

Barrow, L. and Rouse, C.E. (2005). Do returns to schooling differ by race and ethnicity? American Economic Review, 95, 83-87.

Belkin, L. (2003). The opt-out revolution. New York Times, October 26.

Blau, F.D. and Kahn, L.M. (2007). Changes in the labor supply behavior of married women: 19802000. Journal of Labor Economics, 25, 393-438.

Blundell, R. and MaCurdy, T. (1999). Labor supply: A review of alternative approaches. In Ashenfelter, O. and David Card, D. (eds), Handbook of labor economics, vol. 3A. Amsterdam: Elsevier.

Bredemeier, C. and Juessen, F. (2010). Assortative mating and female labor supply. Discussion Paper No. 5118, IZA, Bonn. 
Casper, L.M. and Cohen, P.N. (2000). How does POSSLQ measure up? Historical estimates of cohabitation. Demography, 37, 237-45.

Cawley, J., Heckman, J. and Vytlacil, E. (2001). Three observations on wages and measured cognitive ability. Labour Economics, 8, 419-442.

Cha, Y. (2010). Reinforcing separate spheres: The effect of spousal overwork on the employment of men and women in dual-earner households. American Sociological Review, 75, 303-329.

Connelly, R. and Kimmel, J. (2007). Spousal influences on parents' non-market time choices. Discussion Paper No. 2894, IZA, Bonn.

Farré, L. and Vella, F. (2007). The intergenerational transmission of gender role attitudes and its implications for female labor force participation. Discussion Paper No. 2802, IZA, Bonn.

Fortin, N. (2008). Gender role attitudes and women's labor market participation: Opting-out and the persistent appeal of housewifery. Unpublished manuscript, University of British Columbia.

Goldin, C. (2006). The quiet revolution that transformed women's employment, education, and family. American Economic Review, 96, 1-21.

Hersch, J. and Stratton, L.S. (1994). Housework, wages, and the division of housework time for employed spouses. American Economic Review, 84, 120-125.

Huang, C., Li, H., Liu, P.W. and Zhang, J. (2009). Why does spousal education matter for earnings? assortative mating and cross-productivity. Journal of Labor Economics, 27, 4, 633-652.

Isen, A. and Stevenson, B. (2010). Women's education and family behavior: Trends in marriage, divorce and fertility. Forthcoming in Shoven, J. (ed.), Demography and the Economy. Chicago: University of Chicago Press.

Jaeger, D.A. (1997). Reconciling the old and new Census Bureau education questions: Recommendations for researchers. Journal of Business and Economic Statistics, 15, 300-309.

Johnson, W.R. and Skinner, J. (1986). Labor supply and marital separation. American Economic Review, 76, 455-469.

Kremer, M. (1997). How much does sorting increase inequality? Quarterly Journal of Economics, 112, 115-139.

Madrian, B. and Lefgren, L.J. (2000). An approach to longitudinally matching Current Population Survey (CPS) respondents. Journal of Economic and Social Measurement, 26, 31-62.

Mare, R.D. (1991). Five decades of educational assortative mating. American Journal of Sociology, 56, 15-32.

Oppenheimer, V.K. (2003). Cohabiting and marriage during young men’s career-development process. Demography, 40, 127-149.

Papps, K.L. (2006). The effects of divorce risk on the labour supply of married couples. Discussion Paper No. 2395, IZA, Bonn.

Pencavel, J. (1998). Assortative mating by schooling and the work behavior of wives and husbands. American Economic Review, 88, 326-329.

Percheski, C. (2008). Opting out? Cohort differences in professional women's employment rates from 1960 to 2005. American Sociological Review, 73, 497-517. 
Schwartz, C.R. (2010). Earnings inequality and the changing association between spouses' earnings. American Journal of Sociology, 115, 1524-1557.

Schwartz, C.R. and Mare, R.D. (2005). Trends in educational assortative marriage from 1940 to 2003. Demography, 42, 621-646.

Seltzer, J.A. (2000). Families formed outside of marriage. Journal of Marriage and Family, 62, 12471268.

Shang, Q. and Weinberg, B.A. (2009). Opting for families: Recent trends in the fertility of highly educated women. Working Paper No. 15074, National Bureau of Economic Research, Cambridge, MA.

Srinivas, S. (2007). Social attitudes and the gender pay gap in the USA in recent years. International Journal of Social Economics, 34, 268-275.

Vere, J.P. (2007). “Having it all” no longer: Fertility, female labor supply, and the new life choices of Generation X. Demography, 44, 821-828.

Yun, M.-S. (2005). A simple solution to the identification problem in detailed wage decompositions. Economic Inquiry, 43, 766-772. 


\section{Appendix 1: Data description}

\section{NLSY data}

This study uses NLSY data for 1979-2008 and excludes the military over-sample and the low-income white over-sample, which were discontinued in 1986 and 1991, respectively. The samples only include the observations on respondents after age 25 and while they are married with a spouse aged 25-54. This leaves 3,008 female survey respondents with complete information on all variables, as well as 3,000 women who are married to male survey respondents. The two samples comprise 25,878 and 19,122 person-year observations, respectively.

The NLSY questionnaire contains detailed information on the timing of past changes in marital status, allowing the creation of a complete marital history for each person. Hours worked by a respondent during the year prior to each interview is available. For spouses of respondents, hours worked was constructed by multiplying reported values for weeks worked in the previous year and hours usually worked during these weeks. Annual wage and salary earnings for respondents and their spouses and family other income (from interest, dividends etc.) were expressed in 2000 dollars, using the National Income and Product Account price index for personal consumption expenditures.

Own and spouse hourly wages were constructed by dividing annual earnings by annual hours worked. For those who worked zero hours during a year, had missing earnings or work hours data, received self-employment income or had a wage less than $\$ 2$ or greater than $\$ 200$, a wage rate is either interpolated using information on the person's wage in previous and future years or filled forwards/backwards. For respondents or respondents' spouses who never report a valid wage, the predicted value from a set of log wage regressions is used instead. The regressions were performed separately for each combination of gender and whether the person worked 20 weeks in the past year and included as regressors own and spouse's age, age squared and education, as well as own race/ethnicity (3 categories), region (4 categories) and metropolitan area.

For each respondent, race/ethnicity was determined by which subsample of the NLSY the respondent belonged to: white non-Hispanic, black non-Hispanic or Hispanic. For each respondent and respondent's spouse, the maximum value ever reported for highest schooling grade completed is taken. Four education categories are constructed from this: Grade 11 or less, Grade 12, some college but not a degree 
(defined as Grades 13-15) or a college degree or higher (Grade 16 or above).

\section{CPS data}

Data were taken from the March supplements of the Current Population Survey for 1978-1980, 1988-1990, 1998-2000 and 2008-2010. Households were dropped if either spouse was a member of the armed forces, was not aged 25-54 or had allocated data for annual weeks worked or hours worked per week. The CPS person weights were adjusted so that the sum of the weights in each year was equal. Annual hours worked were created by multiplying the number of weeks worked in the previous year and the number of hours usually worked each week.

An individual's wage and salary earnings were calculated for each year. Since separate variables were included for wage and salary income on respondents' main and secondary jobs for 1988-1990 onwards, the sum of these was used. Blau and Kahn’s (2007) strategy for dealing with top coding was employed. Specifically, since the CPS top code for secondary earnings actually fell from \$99,999 in 1988-1990 to $\$ 25,000$ in $1998-2000$, the later top code was imposed on all years for consistency. All top-coded observations for wage and salary earnings were then multiplied by 1.45. All earnings and income variables were converted into 2000 dollars using the National Income and Product Account price index for personal consumption expenditures.

Hourly wage was defined as wage and salary income divided by annual hours worked. The wage was imputed for individuals who were not employed, had allocated values for earnings, work weeks or work hours, or whose calculated wage was less than $\$ 2$ or greater than $\$ 200$ (in 2000 dollars). The imputed wage value was the predicted value from separate log wage regressions for each combination of gender, period and whether the person worked 20 weeks in the previous year. The regressors used were own and spouse age, age squared, education (4 categories) and race/ethnicity (4 categories), as well as region (9 categories), metropolitan area and year (3 categories).

Values for highest grade completed in 1998-2000 and 2008-2010 were assigned using Jaeger's (1997) correspondence. The same four education categories as in the NLSY sample were then defined for husbands and wives using this. 


\section{Appendix 2: Additional regression tables}

\section{Table A1}

Results with alternative labour supply measures and child interactions

\begin{tabular}{|c|c|c|c|c|}
\hline \multirow[t]{2}{*}{ Variables } & \multirow{2}{*}{$\begin{array}{c}\text { Participation } \\
\text { probit } \\
\text { (i) }\end{array}$} & \multirow{2}{*}{$\begin{array}{c}\text { Hours among } \\
\text { workers } \\
\text { (ii) }\end{array}$} & \multicolumn{2}{|c|}{ Hours among all women } \\
\hline & & & (iii) & (iv) \\
\hline \multicolumn{5}{|l|}{ Own education coefficients } \\
\hline Grade 12 & $\begin{array}{l}0.255^{* * *} \\
(0.046)\end{array}$ & $\begin{array}{l}284.191 * * * \\
(32.616)\end{array}$ & $\begin{array}{c}498.438 * * * \\
(47.749)\end{array}$ & $\begin{array}{c}361.765 * * * \\
(79.166)\end{array}$ \\
\hline Some college & $\begin{array}{c}0.389 * * * \\
(0.050)\end{array}$ & $\begin{array}{c}340.763^{* * *} \\
(34.143)\end{array}$ & $\begin{array}{c}598.591 * * * \\
(50.260)\end{array}$ & $\begin{array}{c}479.884 * * * \\
(81.983)\end{array}$ \\
\hline College graduate & $\begin{array}{c}0.489 * * * \\
(0.057)\end{array}$ & $\begin{array}{c}440.261^{* * *} \\
(36.347)\end{array}$ & $\begin{array}{c}700.497 * * * \\
(54.206)\end{array}$ & $\begin{array}{c}467.008 * * * \\
(86.274)\end{array}$ \\
\hline $\begin{array}{l}\text { Grade } 12 \times \text { child under } \\
6\end{array}$ & - & - & $\begin{array}{c}-149.816 * * \\
(76.125)\end{array}$ & $\begin{array}{l}-103.939 \\
(78.696)\end{array}$ \\
\hline $\begin{array}{l}\text { Some college } \times \text { child } \\
\text { under } 6\end{array}$ & - & - & $\begin{array}{l}-54.608 \\
(78.591)\end{array}$ & $\begin{array}{l}-20.539 \\
(81.332)\end{array}$ \\
\hline $\begin{array}{l}\text { College graduate } \times \text { child } \\
\text { under } 6\end{array}$ & - & - & $\begin{array}{l}-12.521 \\
(82.330)\end{array}$ & $\begin{array}{c}64.069 \\
(84.938)\end{array}$ \\
\hline $\begin{array}{l}\text { Grade } 12 \times \text { years since } \\
\text { marriage }\end{array}$ & - & - & - & $\begin{array}{c}10.332 * * \\
(5.038)\end{array}$ \\
\hline $\begin{array}{l}\text { Some college } \times \text { years } \\
\text { since marriage }\end{array}$ & - & - & - & $\begin{array}{c}8.352 \\
(5.234)\end{array}$ \\
\hline $\begin{array}{l}\text { College graduate } \times \text { years } \\
\text { since marriage }\end{array}$ & - & - & - & $\begin{array}{l}17.532 * * * \\
(5.627)\end{array}$ \\
\hline \multicolumn{5}{|c|}{ Spouse education coefficients } \\
\hline Grade 12 & $\begin{array}{l}0.156 * * * \\
(0.031)\end{array}$ & $\begin{array}{l}-25.871 \\
(18.688)\end{array}$ & $\begin{array}{c}90.947 * * * \\
(30.419)\end{array}$ & $\begin{array}{c}138.217 * * * \\
(51.983)\end{array}$ \\
\hline Some college & $\begin{array}{l}0.111^{* * *} \\
(0.035)\end{array}$ & $\begin{array}{l}-17.648 \\
(20.401)\end{array}$ & $\begin{array}{c}97.636 * * * \\
(33.670)\end{array}$ & $\begin{array}{c}359.811^{* * *} \\
(56.877)\end{array}$ \\
\hline College graduate & $\begin{array}{c}0.116^{* * *} \\
(0.040)\end{array}$ & $\begin{array}{c}-61.735 * * * \\
(22.389)\end{array}$ & $\begin{array}{c}98.136 * * * \\
(37.422)\end{array}$ & $\begin{array}{c}414.444 * * * \\
(61.054)\end{array}$ \\
\hline $\begin{array}{l}\text { Grade } 12 \times \text { child under } \\
6\end{array}$ & - & - & $\begin{array}{l}-16.839 \\
(47.911)\end{array}$ & $\begin{array}{l}-31.720 \\
(50.703)\end{array}$ \\
\hline $\begin{array}{l}\text { Some college } \times \text { child } \\
\text { under } 6\end{array}$ & - & - & $\begin{array}{l}-62.164 \\
(52.468)\end{array}$ & $\begin{array}{c}-162.378 * * * \\
(55.386)\end{array}$ \\
\hline $\begin{array}{l}\text { College graduate } \times \text { child } \\
\text { under } 6\end{array}$ & - & - & $\begin{array}{l}-100.723^{*} \\
(56.535)\end{array}$ & $\begin{array}{c}-211.923^{* * *} \\
(59.309)\end{array}$ \\
\hline $\begin{array}{l}\text { Grade } 12 \times \text { years since } \\
\text { marriage }\end{array}$ & - & - & - & $\begin{array}{l}-4.357 \\
(3.532)\end{array}$ \\
\hline $\begin{array}{l}\text { Some college } \times \text { years } \\
\text { since marriage }\end{array}$ & - & - & - & $\begin{array}{c}-23.838 * * * \\
(3.914)\end{array}$ \\
\hline $\begin{array}{l}\text { College graduate } \times \text { years } \\
\text { since marriage }\end{array}$ & - & - & - & $\begin{array}{c}-30.757 * * * \\
(4.291) \\
\end{array}$ \\
\hline Child under 6 & - & - & $\begin{array}{c}-399.390 * * * \\
(75.950)\end{array}$ & $\begin{array}{c}-387.486 * * * \\
(78.448)\end{array}$ \\
\hline Years since marriage & - & - & - & $\begin{array}{c}-10.130^{* *} \\
(5.147)\end{array}$ \\
\hline AFQT deciles & Yes & Yes & Yes & Yes \\
\hline Pseudo R-squared & 0.079 & 0.004 & 0.011 & 0.012 \\
\hline Number of observations & 25,878 & 21,131 & 25,776 & 25,776 \\
\hline
\end{tabular}

Notes: Tobit estimation is used in columns (ii) and (iii). All models also include controls for own and spouse log wage, household non-labour income, quadratics in own and spouse age and dummy variables for remarriage, school attendance, race/ethnicity (3 categories), region (4 categories), metropolitan area and year (19 categories).

Standard errors are presented in parentheses. *, ** and *** denote significance at the $10 \%, 5 \%$ and $1 \%$ level, respectively. 
Table A2

Results for annual hours equations controlling for selection into marriage

\begin{tabular}{|c|c|c|c|c|}
\hline Variables & 1978-1980 & $1988-1990$ & $1998-2000$ & $2008-2010$ \\
\hline \multicolumn{5}{|l|}{ Own education coefficients } \\
\hline Grade 12 & $\begin{array}{c}296.105^{* * *} \\
(18.765)\end{array}$ & $\begin{array}{c}353.928 * * * \\
(19.213)\end{array}$ & $\begin{array}{c}395.986 * * * \\
(25.335)\end{array}$ & $\begin{array}{c}466.999 * * * \\
(21.524)\end{array}$ \\
\hline Some college & $\begin{array}{c}331.822 * * * \\
(499.320)\end{array}$ & $\begin{array}{c}410.244^{* * * *} \\
(22.035)\end{array}$ & $\begin{array}{c}501.687 * * * \\
(26.843)\end{array}$ & $\begin{array}{c}556.365 * * * \\
(22.591)\end{array}$ \\
\hline College graduate & $\begin{array}{c}499.320 * * * \\
(26.246)\end{array}$ & $\begin{array}{c}460.843^{* * * *} \\
(23.754)\end{array}$ & $\begin{array}{c}627.007 * * * \\
(29.002)\end{array}$ & $\begin{array}{c}631.068 * * * \\
(24.218)\end{array}$ \\
\hline \multicolumn{5}{|c|}{ Spouse education coefficients } \\
\hline Grade 12 & $\begin{array}{c}24.958 \\
(18.123)\end{array}$ & $\begin{array}{c}101.199 * * * \\
(17.937)\end{array}$ & $\begin{array}{c}148.322 * * * \\
(23.076)\end{array}$ & $\begin{array}{c}154.918 * * * \\
(19.617)\end{array}$ \\
\hline Some college & $\begin{array}{l}-25.147 \\
(21.878)\end{array}$ & $\begin{array}{l}92.196 * * * \\
(20.369)\end{array}$ & $\begin{array}{c}123.220 * * * \\
(24.573)\end{array}$ & $\begin{array}{c}145.396 * * * \\
(20.977)\end{array}$ \\
\hline College graduate & $\begin{array}{c}-141.563 * * * \\
(22.799)\end{array}$ & $\begin{array}{c}-63.211^{* * * *} \\
(21.342)\end{array}$ & $\begin{array}{c}-109.547 * * * \\
(26.404)\end{array}$ & $\begin{array}{l}-30.626 \\
(22.415)\end{array}$ \\
\hline $\begin{array}{l}\text { Pseudo R-squared } \\
\text { Number of observations }\end{array}$ & $\begin{array}{c}0.008 \\
50,165\end{array}$ & $\begin{array}{c}0.010 \\
52,210\end{array}$ & $\begin{array}{c}0.008 \\
46,067\end{array}$ & $\begin{array}{c}0.009 \\
72,877\end{array}$ \\
\hline
\end{tabular}

Notes: All models include the same controls as in Table 6. Probit models are used to select a consistent fraction of married couples in each period, as described in the text.

Standard errors are presented in parentheses. *, ** and *** denote significance at the $10 \%, 5 \%$ and $1 \%$ level, respectively. 
Table A3

Decomposition of decadal changes in annual hours

\begin{tabular}{|l|c|c|c|c|c|c|}
\hline \multirow{2}{*}{ Variables } & \multicolumn{2}{|c|}{$1980-1990$} & \multicolumn{2}{c|}{$1990-2000$} & \multicolumn{2}{c|}{$2000-2010$} \\
\cline { 2 - 7 } & $\Delta x$ & $\Delta \beta$ & $\Delta x$ & $\Delta \beta$ & $\Delta x$ & $\Delta \beta$ \\
\hline Own wage & 69.165 & 89.057 & 102.048 & -416.006 & 51.140 & 148.290 \\
Spouse's wage & 1.189 & 102.339 & -8.524 & 114.010 & -15.287 & -11.329 \\
Own education & 24.101 & 9.222 & 18.991 & 7.772 & 16.559 & -5.096 \\
Spouse's education & -5.095 & 2.975 & -1.455 & 1.100 & -5.173 & 6.097 \\
Non-labour income & -2.604 & 1.667 & -2.862 & 5.372 & 1.264 & -1.022 \\
Own age & 2.730 & 71.670 & 5.973 & 205.179 & 3.437 & -214.738 \\
Spouse's age & -3.058 & -155.669 & 3.565 & -807.901 & 3.903 & 157.901 \\
Own race/ethnicity & -1.099 & -4.684 & 1.433 & -15.907 & -1.945 & -49.040 \\
Spouse’s race/ethnicity & 1.078 & 29.780 & -2.458 & 2.244 & -1.400 & 9.866 \\
Region/metropolitan area & -1.119 & -7.839 & 0.370 & -34.128 & -1.300 & -6.591 \\
\hline All variables & 85.492 & 212.017 & 116.909 & 7.645 & 51.185 & -70.478 \\
\hline Total change & \multicolumn{2}{|c|}{297.509} & \multicolumn{2}{c|}{124.554} & \multicolumn{2}{c|}{-19.293} \\
\hline
\end{tabular}

Notes: $\Delta x$ denotes the effect of changes in characteristics between periods, using the equation for the start period; $\Delta \beta$ denotes the effect of changes in coefficients, holding the characteristics fixed at their average values for the end period.

Coefficients are taken from linear regression estimates of Equation 11 for each period.

For own and spouse education and race/ethnicity and for region, $\Delta x$ and $\Delta \beta$ are averaged over all choices of reference category, as proposed by Yun (2005). 
Table A4

Results for annual hours equation with child interactions

\begin{tabular}{|c|c|c|c|c|}
\hline Variables & 1978-1980 & 1988-1990 & $1998-2000$ & 2008-2010 \\
\hline \multicolumn{5}{|l|}{ Own education coefficients } \\
\hline Grade 12 & $\begin{array}{c}347.168^{* * *} \\
(17.600)\end{array}$ & $\begin{array}{c}399.250 * * * \\
(19.106)\end{array}$ & $\begin{array}{c}373.531 * * * \\
(26.338)\end{array}$ & $\begin{array}{c}402.530 * * * \\
(24.816)\end{array}$ \\
\hline Some college & $\begin{array}{c}390.162 * * * \\
(23.458)\end{array}$ & $\begin{array}{c}460.011^{* * *} \\
(22.609)\end{array}$ & $\begin{array}{c}489.781^{* * *} \\
(28.158)\end{array}$ & $\begin{array}{c}476.188 * * * \\
(25.968)\end{array}$ \\
\hline College graduate & $\begin{array}{c}556.627 * * * \\
(26.191)\end{array}$ & $\begin{array}{c}526.684 * * * \\
(24.504)\end{array}$ & $\begin{array}{c}610.596 * * * \\
(30.473)\end{array}$ & $\begin{array}{c}532.384 * * * \\
(27.620)\end{array}$ \\
\hline Grade $12 \times$ child under 6 & $\begin{array}{l}-60.329 \\
(36.797)\end{array}$ & $\begin{array}{l}-54.901 \\
(38.114)\end{array}$ & $\begin{array}{c}160.442 * * * \\
(51.063)\end{array}$ & $\begin{array}{c}121.010 * * * \\
(46.146)\end{array}$ \\
\hline $\begin{array}{l}\text { Some college } \times \text { child } \\
\text { under } 6\end{array}$ & $\begin{array}{l}-54.492 \\
(45.172)\end{array}$ & $\begin{array}{l}-22.994 \\
(42.824)\end{array}$ & $\begin{array}{c}156.750 * * * \\
(53.311)\end{array}$ & $\begin{array}{c}216.242 * * * \\
(47.253)\end{array}$ \\
\hline $\begin{array}{l}\text { College graduate } \times \text { child } \\
\text { under } 6\end{array}$ & $\begin{array}{l}-34.476 \\
(48.875)\end{array}$ & $\begin{array}{l}-31.376 \\
(44.805)\end{array}$ & $\begin{array}{c}202.833 * * * \\
(55.950)\end{array}$ & $\begin{array}{c}331.318 * * * \\
(48.574)\end{array}$ \\
\hline \multicolumn{5}{|c|}{ Spouse education coefficients } \\
\hline Grade 12 & $\begin{array}{l}33.021^{*} \\
(17.439)\end{array}$ & $\begin{array}{l}88.251^{* * *} \\
(18.352)\end{array}$ & $\begin{array}{c}144.996 * * * \\
(24.704)\end{array}$ & $\begin{array}{c}148.558 * * * \\
(22.506)\end{array}$ \\
\hline Some college & $\begin{array}{c}22.441 \\
(21.882)\end{array}$ & $\begin{array}{l}107.261^{* * *} \\
(21.279)\end{array}$ & $\begin{array}{c}131.038 * * * \\
(26.430)\end{array}$ & $\begin{array}{c}149.683 * * * \\
(24.034)\end{array}$ \\
\hline College graduate & $\begin{array}{l}-65.752 * * * \\
(22.854)\end{array}$ & $\begin{array}{c}18.932 \\
(22.293)\end{array}$ & $\begin{array}{l}-19.334 \\
(28.243)\end{array}$ & $\begin{array}{c}33.902 \\
(25.494)\end{array}$ \\
\hline Grade $12 \times$ child under 6 & $\begin{array}{c}-72.884 * * \\
(36.325)\end{array}$ & $\begin{array}{l}-27.232 \\
(36.039)\end{array}$ & $\begin{array}{l}-47.827 \\
(47.798)\end{array}$ & $\begin{array}{c}-6.415 \\
(42.509)\end{array}$ \\
\hline $\begin{array}{l}\text { Some college } \times \text { child } \\
\text { under } 6\end{array}$ & $\begin{array}{c}-113.199 * * * \\
(42.386)\end{array}$ & $\begin{array}{c}-97.930 * * \\
(40.301)\end{array}$ & $\begin{array}{l}-79.928 \\
(50.509)\end{array}$ & $\begin{array}{l}-17.754 \\
(44.886)\end{array}$ \\
\hline $\begin{array}{l}\text { College graduate } \times \text { child } \\
\text { under } 6\end{array}$ & $\begin{array}{c}-171.956 * * * \\
(43.897) \\
\end{array}$ & $\begin{array}{c}-224.105^{* * *} \\
(41.079) \\
\end{array}$ & $\begin{array}{c}-283.347^{* * *} \\
(52.588) \\
\end{array}$ & $\begin{array}{c}-182.382 * * * \\
(46.031) \\
\end{array}$ \\
\hline Child under 6 & $\begin{array}{c}-698.050 * * * \\
(33.350) \\
\end{array}$ & $\begin{array}{c}-499.062 * * * \\
(34.774) \\
\end{array}$ & $\begin{array}{c}-570.683 * * * \\
(45.485) \\
\end{array}$ & $\begin{array}{c}-659.295 * * * \\
(39.550) \\
\end{array}$ \\
\hline $\begin{array}{l}\text { Pseudo R-squared } \\
\text { Number of observations }\end{array}$ & $\begin{array}{c}0.014 \\
60,850 \\
\end{array}$ & $\begin{array}{c}0.014 \\
58,688 \\
\end{array}$ & $\begin{array}{c}0.011 \\
49,382 \\
\end{array}$ & $\begin{array}{c}0.011 \\
72,877 \\
\end{array}$ \\
\hline
\end{tabular}

Notes: Tobit estimation is used. All models include the same controls as in Table 6.

Standard errors are presented in parentheses. *, ** and *** denote significance at the $10 \%, 5 \%$ and $1 \%$ level, respectively. 